\title{
Signaling Pathways in Bone Development and Their Related Skeletal Dysplasia
}

\author{
Alessandra Guasto ${ }^{1}$ and Valérie Cormier-Daire ${ }^{1,2, *(D)}$ \\ 1 Imagine Institute, Université de Paris, Clinical Genetics, INSERM UMR 1163, Necker Enfants Malades \\ Hospital, 75015 Paris, France; alessandra.guasto@institutimagine.org \\ 2 Centre de Référence Pour Les Maladies Osseuses Constitutionnelles, Service de Génétique Clinique, AP-HP, \\ Hôpital Necker-Enfants Malades, 75015 Paris, France \\ * Correspondence: valerie.cormier-daire@inserm.fr; Tel.: +33-1-44-49-51-63; Fax: +33-1-42-75-42-23
}

Citation: Guasto, A.; Cormier-Daire, V. Signaling Pathways in Bone Development and Their Related Skeletal Dysplasia. Int. J. Mol. Sci. 2021, 22, 4321. https://doi.org/ $10.3390 /$ ijms 22094321

Academic Editor: Pierre Moffatt

Received: 16 March 2021

Accepted: 19 April 2021

Published: 21 April 2021

Publisher's Note: MDPI stays neutral with regard to jurisdictional claims in published maps and institutional affiliations.

Copyright: (c) 2021 by the authors. Licensee MDPI, Basel, Switzerland. This article is an open access article distributed under the terms and conditions of the Creative Commons Attribution (CC BY) license (https:// creativecommons.org/licenses/by/ $4.0 /)$.

\begin{abstract}
Bone development is a tightly regulated process. Several integrated signaling pathways including HH, PTHrP, WNT, NOTCH, TGF- $\beta$, BMP, FGF and the transcription factors SOX9, RUNX2 and OSX are essential for proper skeletal development. Misregulation of these signaling pathways can cause a large spectrum of congenital conditions categorized as skeletal dysplasia. Since the signaling pathways involved in skeletal dysplasia interact at multiple levels and have a different role depending on the time of action (early or late in chondrogenesis and osteoblastogenesis), it is still difficult to precisely explain the physiopathological mechanisms of skeletal disorders. However, in recent years, significant progress has been made in elucidating the mechanisms of these signaling pathways and genotype-phenotype correlations have helped to elucidate their role in skeletogenesis. Here, we review the principal signaling pathways involved in bone development and their associated skeletal dysplasia.
\end{abstract}

Keywords: bone development; signaling pathways; skeletal dysplasia

\section{Introduction}

Skeletal development in mammals occurs through two distinct mechanisms: intramembranous and endochondral ossification. In the intramembranous process, osteoblast cells differentiate directly from mesenchymal cells and form flat bones like cranial vault, parts of the jaw and lateral clavicles. At the end of the bone formation period, osteoblasts die by apoptosis or become embedded in the matrix as osteocytes, which then eventually undergo apoptosis [1]. In the endochondral process, which forms the rest of the skeleton, the mesenchymal cells condensate and differentiate in chondrocytes that deposit a cartilaginous model. Then, chondrocytes proliferate, forming the growth plate and secreting a cartilage-specific extracellular matrix. Afterwards, chondrocytes in the center of the cartilage arrest to divide and increase their volume, becoming hypertrophic chondrocytes $[2,3]$. The hypertrophic chondrocytes have the capacity to mineralize their extracellular matrix and can die by apoptosis or differentiate into osteoblasts. With the invasion of the cartilage model by blood vessels, stem cells of different lineages give rise to the bone depositing osteoblasts and the bone resorbing osteoclasts forming the primary ossification center. After formation of a secondary ossification center within the cartilaginous epiphyses during the early postnatal stage, the definitive growth plate can be identified by well-demarcated zones of cells representing the maturation steps of chondrocytes (resting, proliferative, prehypertrophic and hypertrophic) and remains, in humans, until puberty.

Both ossification processes are strictly regulated by several signaling pathways grouped by their response to the following signaling ligand families: Hedgehog $(\mathrm{HH})$, Parathyroid Hormone-related Protein (PTHrP), Wingless and int-1 (WNT), NOTCH, Transforming Growth Factor-beta (TGF- $\beta$ ), Bone Morphogenic Protein (BMP) and Fibroblast Growth 
Factor (FGF). These pathways converge on specific transcription factors including SRYrelated HMG-box 9 (SOX9), Runt-related transcription factor 2 (RUNX2) and Osterix (OSX). Dysregulation of these signaling pathways cause a large spectrum of skeletal diseases. Skeletal dysplasia (SD), also named osteochondrodysplasia, is a group of rare genetic disorders mainly characterized by cartilage and bone growth anomalies. Today, thanks to next-generation DNA sequencing, 461 different SD have been recognized and classified in 42 groups depending on their clinical, radiographic and/or molecular bases [4]. Here, we review the most important signaling pathways involved in bone development and the $\mathrm{SD}$ associated with signaling impairment. All SD mentioned in this review are listed in Table 1.

Table 1. Signaling pathways involved in bone development and associated skeletal dysplasia.

\begin{tabular}{|c|c|c|c|}
\hline $\begin{array}{c}\text { Signaling } \\
\text { Pathway/Transcription } \\
\text { Factor }\end{array}$ & Associated Disease & Gene(s) & OMIM Number \\
\hline \multirow[t]{13}{*}{$\mathrm{HH}$} & Werner syndrome & $\mathrm{SHH}$ & 188,740 \\
\hline & Acheiropodia & $\mathrm{SHH}$ & 200,500 \\
\hline & $\begin{array}{c}\text { Preaxial polydactyly type } \\
1 \text { (PPD1) }\end{array}$ & $\mathrm{SHH}$ & 174,400 \\
\hline & $\begin{array}{c}\text { Preaxial polydactyly type } \\
2 \text { (PPD2) }\end{array}$ & $\mathrm{SHH}$ & 174,500 \\
\hline & $\begin{array}{c}\text { Syndactyly type } 4(\mathrm{I}-\mathrm{V}) \\
\text { Haas type }\end{array}$ & $\mathrm{SHH}$ & 186,200 \\
\hline & $\begin{array}{l}\text { Laurin-Sandrow } \\
\text { syndrome }\end{array}$ & SHH & 135,750 \\
\hline & $\begin{array}{c}\text { Preaxial polydactyly type } \\
4 \text { (PPD4) }\end{array}$ & GLI3 & 174,700 \\
\hline & Pallister-Hall syndrome & GLI3 & 146,510 \\
\hline & $\begin{array}{c}\text { Grieg } \\
\text { cephalopolysyndactyly }\end{array}$ & GLI3 & 175,700 \\
\hline & $\begin{array}{c}\text { Acrocapitofemoral } \\
\text { dysplasia }\end{array}$ & $I H H$ & 607,778 \\
\hline & $\begin{array}{l}\text { Syndactyly with } \\
\text { craniosynostosis } \\
\text { (Philadelphia type) }\end{array}$ & $I H H$ & 185,900 \\
\hline & Syndactyly Lueken type & $I H H$ & \\
\hline & Brachydactyly type A1 & $I H H$ & 112,500 \\
\hline \multirow[t]{5}{*}{ PTHrP } & Blomstrand dysplasia & PTHR1 & 215,045 \\
\hline & $\begin{array}{l}\text { Metaphyseal dysplasia, } \\
\text { Jansen type }\end{array}$ & PTHR1 & 156,400 \\
\hline & Eiken dysplasia & PTHR1 & 600,002 \\
\hline & Acrodysostosis & $\begin{array}{c}\text { PDE4D } \\
\text { PRKAR1A }\end{array}$ & $\begin{array}{l}614,613 \\
101,800 \\
\end{array}$ \\
\hline & Brachydactyly type E & PTHLH & 613,382 \\
\hline $\begin{array}{c}\text { Signaling } \\
\text { pathway/Transcription } \\
\text { factor }\end{array}$ & Associated disease & Gene(s) & OMIM number \\
\hline PTHrP & $\begin{array}{l}\text { Pseudohypoparathyroidism } \\
\text { type IA (Albright } \\
\text { hereditary } \\
\text { osteodystrophy) }\end{array}$ & GNAS & 103,580 \\
\hline
\end{tabular}


Table 1. Cont.

\begin{tabular}{|c|c|c|c|}
\hline $\begin{array}{c}\text { Signaling } \\
\text { Pathway/Transcription } \\
\text { Factor }\end{array}$ & Associated Disease & Gene(s) & OMIM Number \\
\hline & $\begin{array}{l}\text { Fibrous dysplasia, } \\
\text { polyostotic form } \\
\text { (McCune-Albright) }\end{array}$ & GNAS & 174,800 \\
\hline & $\begin{array}{l}\text { Brachydactyly-mental } \\
\text { retardation syndrome }\end{array}$ & HDAC4 & 600,430 \\
\hline \multirow[t]{16}{*}{ WNT } & $\begin{array}{c}\text { Osteogenesis imperfecta, } \\
\text { progressively deforming } \\
\text { type (OI type } 3)\end{array}$ & WNT1 & 615,220 \\
\hline & $\begin{array}{l}\text { Osteogenesis imperfecta, } \\
\text { moderate form (OI type } \\
4 \text { ) }\end{array}$ & WNT1 & 615,220 \\
\hline & $\begin{array}{c}\text { Tetra-amelia syndrome } \\
\text { type } 1\end{array}$ & WNT3 & 273,395 \\
\hline & $\begin{array}{l}\text { Robinow syndrome } \\
\text { dominant type }\end{array}$ & WNT5A & 180,700 \\
\hline & $\begin{array}{l}\text { Acro-pectoro-vertebral } \\
\text { dysplasia (F-syndrome) }\end{array}$ & WNT6 & 102,510 \\
\hline & $\begin{array}{c}\text { Al-Awadi } \\
\text { Raas-Rothschild } \\
\text { limb-pelvis } \\
\text { hypoplasiaaplasia }\end{array}$ & WNT7A & 276,820 \\
\hline & Furhmann syndrome & WNT7A & 228,930 \\
\hline & $\begin{array}{l}\text { Split-hand-foot } \\
\text { malformation, isolated } \\
\text { form, type } 6 \text { (SHFM6) }\end{array}$ & WNT10B & 225,300 \\
\hline & $\begin{array}{l}\text { Robinow syndrome } \\
\text { recessive type }\end{array}$ & ROR2 & 268,310 \\
\hline & Brachydactyly type B & ROR2 & 113,000 \\
\hline & Cenani-Lenz syndactyly & LRP4 & 212,780 \\
\hline & $\begin{array}{l}\text { Osteoporosis- } \\
\text { pseudoglioma } \\
\text { syndrome }\end{array}$ & LRP5 & 259,770 \\
\hline & Osteosclerosis & LRP5 & 144,750 \\
\hline & Osteoporosis-AD form & $\begin{array}{l}\text { LRP5 } \\
\text { WNT1 }\end{array}$ & $\begin{array}{l}166,710 \\
615,220\end{array}$ \\
\hline & Osteopetrosis type 1 & LRP5 & 607,634 \\
\hline & Sclerosteosis & $\begin{array}{l}\text { SOST } \\
\text { LRP4 }\end{array}$ & $\begin{array}{l}269,500 \\
614,305\end{array}$ \\
\hline $\begin{array}{c}\text { Signaling } \\
\text { pathway/Transcription } \\
\text { factor }\end{array}$ & Associated disease & Gene(s) & OMIM number \\
\hline WNT & $\begin{array}{c}\text { Endostheal hyperostosis, } \\
\text { van Buchem type }\end{array}$ & SOST & 239,100 \\
\hline & $\begin{array}{c}\text { Craniodiaphyseal } \\
\text { dysplasia }\end{array}$ & SOST & 122,860 \\
\hline
\end{tabular}


Table 1. Cont.

\begin{tabular}{|c|c|c|c|}
\hline $\begin{array}{c}\text { Signaling } \\
\text { Pathway/Transcription } \\
\text { Factor }\end{array}$ & Associated Disease & Gene(s) & OMIM Number \\
\hline & $\begin{array}{c}\text { Cenani-Lenz-like } \\
\text { non-syndromic bilateral } \\
\text { oligosyndatyly }\end{array}$ & GREM1 & \\
\hline & Pyle disease & SFRP4 & 265,900 \\
\hline & $\begin{array}{l}\text { Osteopathia striata with } \\
\text { cranial sclerosis (OSCS) }\end{array}$ & AMER1 & 300,373 \\
\hline & $\begin{array}{l}\text { Tetra-amelia syndrome } \\
\text { type } 2\end{array}$ & RSPO2 & 618,021 \\
\hline & Omodysplasia type 1 & GPC6 & 258,315 \\
\hline \multirow[t]{4}{*}{ NOTCH } & $\begin{array}{l}\text { Spondylocostal } \\
\text { dysostosis }\end{array}$ & $\begin{array}{l}\text { DLL3 } \\
\text { MESP2 } \\
\text { HES7 } \\
\text { LFNG }\end{array}$ & $\begin{array}{l}277,300 \\
608,681 \\
613,686 \\
609,813\end{array}$ \\
\hline & $\begin{array}{l}\text { Vertebral segmentation } \\
\text { defect (congenital } \\
\text { scoliosis) with variable } \\
\text { penetrance }\end{array}$ & $\begin{array}{l}\text { MESP2 } \\
\text { HES7 }\end{array}$ & $\begin{array}{l}608,681 \\
613,686\end{array}$ \\
\hline & Hajdu-Cheney syndrome & NOTCH2 & 102,500 \\
\hline & Adams-Oliver syndrome & $\begin{array}{l}\text { NOTCH1 } \\
\text { DLL4 } \\
\text { RBPJ }\end{array}$ & $\begin{array}{l}616,028 \\
616,589 \\
614,814\end{array}$ \\
\hline \multirow[t]{5}{*}{$\mathrm{BMP} / \mathrm{TGF} \beta$} & $\begin{array}{l}\text { Multiple synostoses } \\
\text { syndrome }\end{array}$ & $\begin{array}{l}\text { NOG } \\
\text { GDF5 } \\
\text { GDF6 }\end{array}$ & $\begin{array}{l}186,500 \\
610,017 \\
617,898\end{array}$ \\
\hline & Brachydactyly type B2 & NOG & 611,377 \\
\hline & Klippel-Feil syndrome & GDF6 & 118,100 \\
\hline & $\begin{array}{c}\text { Acromesomelic dysplasia } \\
\text { (Grebe dysplasia) }\end{array}$ & $\begin{array}{c}\text { GDF5 } \\
\text { BMPR1B }\end{array}$ & $\begin{array}{l}200,700 \\
609,441 \\
\end{array}$ \\
\hline & $\begin{array}{c}\text { Acromesomelic dysplasia } \\
\text { (Fibular hypoplasia and } \\
\text { complex brachydactyly, } \\
\text { Du Pan) }\end{array}$ & $\begin{array}{c}\text { GDF5 } \\
\text { BMPR1B }\end{array}$ & 228,900 \\
\hline $\begin{array}{c}\text { Signaling } \\
\text { pathway/Transcription } \\
\text { factor }\end{array}$ & Associated disease & Gene(s) & OMIM number \\
\hline \multirow[t]{5}{*}{$\mathrm{BMP} / \mathrm{TGF} \beta$} & Diaphanospondylodysostosis & BMPER & 608,022 \\
\hline & $\begin{array}{c}\text { Fibrodysplasia ossificans } \\
\text { progressive (FOP) }\end{array}$ & ACVR1 & 135,100 \\
\hline & $\begin{array}{l}\text { Diaphyseal dysplasia } \\
\text { Camurati Engelmann }\end{array}$ & TGFB1 & 131,300 \\
\hline & Myhre syndrome & SMAD4 & 139,210 \\
\hline & $\begin{array}{l}\text { Loeys-Dietz syndrome } \\
\text { (types 1-6) }\end{array}$ & $\begin{array}{c}\text { TGFBR1 } \\
\text { TGFBR2 } \\
\text { SMAD3 } \\
\text { TGFB2 } \\
\text { TGFB3 } \\
\text { SMAD2 }\end{array}$ & $\begin{array}{l}609,192 \\
610,168 \\
613,795 \\
614,816 \\
615,582 \\
601,366\end{array}$ \\
\hline
\end{tabular}


Table 1. Cont.

\begin{tabular}{|c|c|c|c|}
\hline \multirow[t]{8}{*}{$\begin{array}{c}\text { Signaling } \\
\text { Pathway/Transcription } \\
\text { Factor }\end{array}$} & Associated Disease & Gene(s) & OMIM Number \\
\hline & \multirow{3}{*}{ Brachydactyly type A2 } & $B M P R 1 B$ & 112,600 \\
\hline & & $B M P 2$ & 112,600 \\
\hline & & GDF5 & 112,600 \\
\hline & Brachydactyly type C & GDF5 & 113,100 \\
\hline & Osteopoikilosis & LEMD3 & 166,700 \\
\hline & $\begin{array}{l}\text { Melorheostosis with } \\
\text { osteopoikilosis }\end{array}$ & LEMD3 & 166,700 \\
\hline & $\begin{array}{l}\text { Shprintzen-Goldberg } \\
\text { syndrome }\end{array}$ & $S K I$ & 182,212 \\
\hline \multirow[t]{15}{*}{ FGF } & $\begin{array}{c}\text { Thanatophoric dysplasia } \\
\text { type } 1\end{array}$ & FGFR3 & 187,600 \\
\hline & $\begin{array}{c}\text { Thanatophoric dysplasia } \\
\text { type } 2\end{array}$ & FGFR3 & 187,601 \\
\hline & SADDAN & FGFR3 & 616,482 \\
\hline & Achondroplasia & FGFR3 & 100,800 \\
\hline & Hypochondroplasia & FGFR3 & 146,000 \\
\hline & $\begin{array}{l}\text { Camptodactyly, tall } \\
\text { stature and hearing loss } \\
\text { syndrome (CATSHL) }\end{array}$ & FGFR3 & 610,474 \\
\hline & Bent bone dysplasia & FGFR2 & 614,592 \\
\hline & Osteoglophonic dyplsasia & FGFR1 & 166,250 \\
\hline & \multirow{2}{*}{ Pfeiffer syndrome } & FGFR1 & 101,600 \\
\hline & & FGFR2 & 101,600 \\
\hline & \multirow{2}{*}{ Jackson-Weiss syndrome } & FGFR2 & 123,150 \\
\hline & & FGFR1 & 123,150 \\
\hline & Apert syndrome & FGFR2 & 101,200 \\
\hline & $\begin{array}{c}\text { Craniosynostosis with } \\
\text { cutis gyrata } \\
\text { (Beare-Stevenson) }\end{array}$ & FGFR2 & 123,790 \\
\hline & Crouzon syndrome & FGFR2 & 123,500 \\
\hline $\begin{array}{c}\text { Signaling } \\
\text { pathway/Transcription } \\
\text { factor }\end{array}$ & Associated disease & Gene(s) & OMIM number \\
\hline \multirow[t]{8}{*}{ FGF } & $\begin{array}{l}\text { Saethre-Chotzen } \\
\text { syndrome }\end{array}$ & FGFR2 & \\
\hline & $\begin{array}{l}\text { Crouzon-like with } \\
\text { achantosis nigricans }\end{array}$ & FGFR3 & 612,247 \\
\hline & $\begin{array}{l}\text { Craniosynostosis } \\
\text { Muenke type }\end{array}$ & FGFR3 & 602,849 \\
\hline & $\begin{array}{l}\text { Multiple synostosis } \\
\text { syndrome type } 3\end{array}$ & FGF9 & 612,961 \\
\hline & Hartsfield syndrome & FGFR1 & 615,465 \\
\hline & Lacrimo-auriculo-dento- & FGFR2 & \\
\hline & digital syndrome & FGFR3 & 149,730 \\
\hline & $(\mathrm{LADD})$ & FGF10 & \\
\hline
\end{tabular}


Table 1. Cont.

\begin{tabular}{cccc}
\hline $\begin{array}{c}\text { Signaling } \\
\text { Pathway/Transcription } \\
\text { Factor }\end{array}$ & Associated Disease & Gene(s) & OMIM Number \\
\hline & $\begin{array}{c}\text { Hyperostosis- } \\
\text { Hyperphosphatemia } \\
\text { syndrome }\end{array}$ & FGF23 & 617,993 \\
& $\begin{array}{c}\text { Acromesomelic dysplasia } \\
\text { type Maroteaux }\end{array}$ & NPR2 & 602,875 \\
\hline & $\begin{array}{c}\text { Tall stature with long } \\
\text { halluces, NPR2 type }\end{array}$ & NPR2 & 615,923 \\
\hline SOX9 & Campomelic dysplasia & SOX9 & 114,290 \\
\hline RUNX2 & $\begin{array}{c}\text { Metaphyseal dysplasia } \\
\text { with maxillary } \\
\text { hypoplasia }\end{array}$ & RUNX2 & 156,510 \\
\hline & Cleidocranial dysplasia & RUNX2 & 119,600 \\
\hline SP7/Osterix & $\begin{array}{l}\text { Osteogenesis imperfecta, } \\
\text { moderate form (OI type } \\
4 \text { ) }\end{array}$ & SP7 & 613,849 \\
\hline
\end{tabular}

\section{Hedgehog Signaling}

Hedgehog $(\mathrm{HH})$ signaling is involved in many developmental processes, such as growth, patterning and morphogenesis of many tissues. In mammals, three $\mathrm{HH}$ ligands are produced: Sonic (SHH), Indian ( $\mathrm{IHH})$, and Desert Hedgehog (DHH). HH ligands interact with the 12-pass transmembrane Patched receptors (PTCH 1 and 2) causing the activation of the smoothened (SMO) protein, a 7- pass transmembrane protein with intrinsic intracellular activity. Its translocation to the base of primary cilium activates Gli transcriptor factors (GLI 1, 2 and 3) [5-7]. In vertebrates, SHH and IHH are the principal ligands involved in skeletal development. SHH is involved in the first stages of mesenchymal condensation. It promotes the epithelial-mesenchymal transition of sclerotome, the skeletogenic mesenchyme from which the intervertebral discs, vertebrae and ribs are derived $[8,9]$. SHH is also expressed in the developing face and regulates the outgrowth and the differentiation of the cranial-neural crest cell-derived skeletal structures [10,11]. Moreover, $\mathrm{SHH}$ have a critical role in digit patterning in the appendicular skeleton [12]. On the other hand, IHH is implicated in skeleton formation and in particular in endochondral ossification [5,6]. IHH is strongly expressed in the growth plate by pre- and early hypertrophic chondrocytes. It regulates chondrocyte hypertrophy in an indirect manner through a negative feedback loop with parathyroid hormone-related peptide (PTHrP), and directly promotes chondrocyte proliferation and osteoblast specification (Figure 1A) [13-15].

In the first case, IHH upregulates the expression of PTHrP, which maintains growth plate chondrocytes in a proliferative state and inhibits their hypertrophic maturation [16]. Indeed, the maintenance of proliferation promoted by PTHrP inhibits IHH production, since it is expressed by prehypertrophic chondrocytes and not by proliferative chondrocytes $[15,17]$. In the second case, IHH promotes chondrocyte proliferation in a direct manner by inhibiting the GLI3 activity and promoting the transition of round chondrocyte into proliferating chondrocytes [14,18]. 


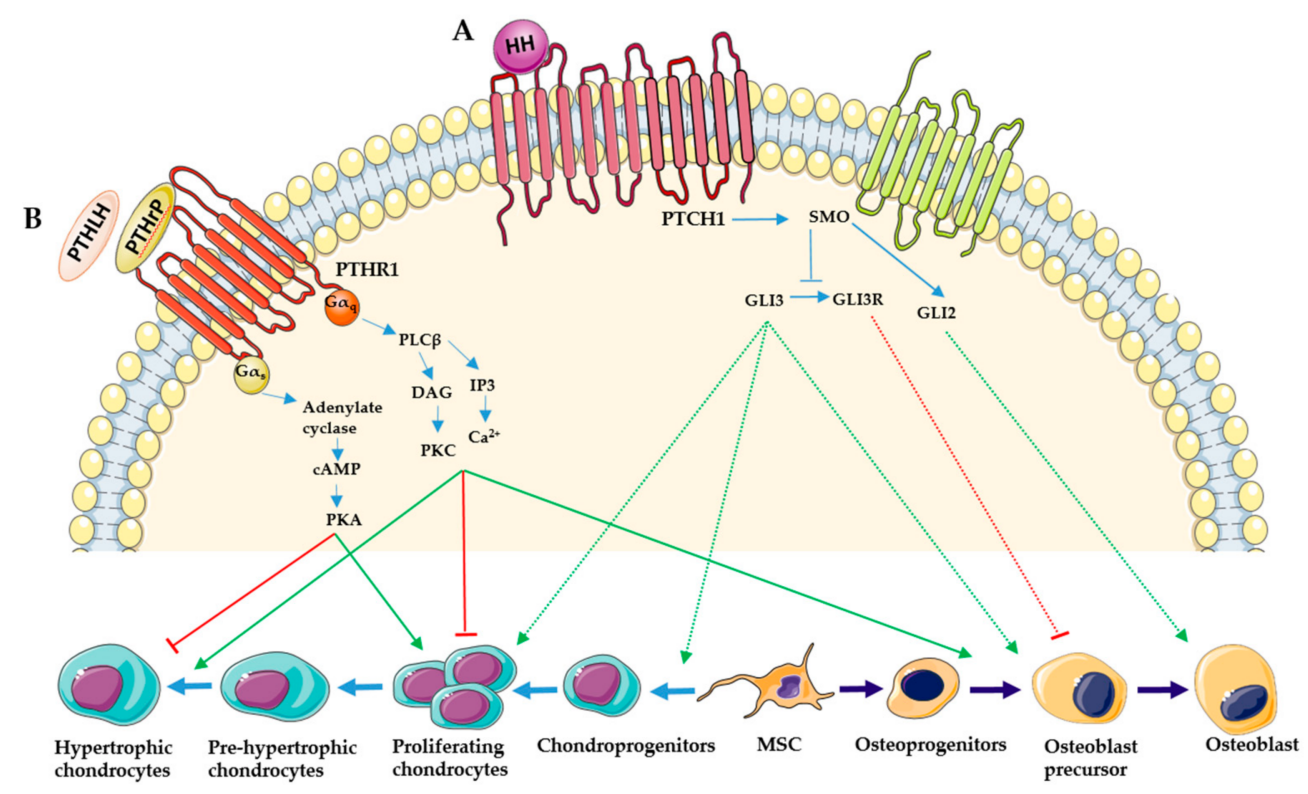

Figure 1. $\mathrm{HH}$ and PTHrP signaling pathways in chondrocyte and osteoblast differentiation (A) $\mathrm{HH}$ ligands interact with PTCH 1 receptor causing the activation of the SMO protein and in consequence, the activation of GLI transcriptor factors. HH signaling positively regulates the first steps of chondrogenesis from mesenchymal stem cells (MSC) and chondrocyte proliferation. It induces the specification of osteoblast precursors and the maturation in mature osteoblasts. The activation of the GLI3 repressor (GLI3R) inhibits osteoblast precursor proliferation. (B) PTHrP or PTHLH bind to PTHR1 activating G $\alpha$ s and G $\alpha$ q proteins. Through G $\alpha$ s, PTHrP activates adenylate cyclase and the production of CAMP, which in turn activates PKA proteins inducing chondrocyte proliferation and inhibiting their hypertrophic differentiation. However, through G $\alpha q$, PTHrP activates PLC $\beta$ and the production of DAG and IP3, leading to the activation of PKC and to an increase of intracellular $\mathrm{Ca}^{2+}$, respectively. PLC $\beta$ signaling inhibits chondrocyte proliferation and induces their hypertrophic differentiation and osteoblast differentiation.

$\mathrm{HH}$ is also involved in osteoblast development during ossification. In endochondral ossification, IHH produced by pre-hypertrophic and hypertrophic chondrocytes acts on osteoblast progenitors to induce the specification in Runx2-positive osteoblast precursors in the perichondrium and the primary spongiosa $[19,20]$. In addition to osteoblast differentiation in the perichondrium, $\mathrm{HH}$ signaling is also fundamental for trabecular bone formation [21].

As demonstrated by all these studies, $\mathrm{HH}$ signaling is critical for bone development and its misregulation results in several human skeletal diseases associated with a wide spectrum of limb and facial skeletal anomalies. In particular, as mentioned before, $\mathrm{HH}$ ligands diffuse across the developing limb bud and produce a concentration gradient that acts as a morphogen to specify digit development. HH signaling activating mutations, like those inactivating GLI3 repressor, cause polydactyly in Greig cephalopolysyndactyly syndrome, Pallister-Hall syndrome and Preaxial polydactyly type 4 [22-26], while missense heterozygous mutations in $I H H$ cause brachydactyly type A1 $[24,25,27]$. Mutations in $I H H$ have also been associated with Syndactyly with craniosynostosis [28], Syndactyly Lueken type [29] and acrocapitofemoral dysplasia [30]. This last disorder is caused by missense mutations causing an increased chondrocyte differentiation by diminishing IHH signaling in the growth plate. The phenotype is characterized by short stature with short limbs and highlights the importance of $\mathrm{IHH}$ in coordinating chondrocyte proliferation and differentiation. On the other hand, $\mathrm{SHH}$ mutations cause congenital hand deformities and severe craniofacial and neurological syndromes like Werner syndrome, Acheiropodia [31], different forms of polydactyly and syndactyly [32], and Laurin-Sandrow syndrome [33]. 


\section{Parathyroid Hormone-Related Protein}

PTHrP is a paracrine factor expressed by cartilage and bone. In particular, $\mathrm{PTHrP}$ is expressed by periarticular resting cells of the perichondrium and at a lower level by proliferating chondrocytes $[19,34]$. PTHrP binds to a specific receptor (PTHR1), which is G-protein coupled and is composed of seven transmembrane domains [35]. PTHR1 is expressed at low levels by proliferating chondrocytes and at a higher level in prehypertrophic chondrocytes $[17,19]$. Upon ligand binding, receptor activation results in stimulation of the heteromeric $(\alpha \beta \gamma)$ guanine nucleotide binding proteins $\left(G \alpha_{s}\right.$ and $\left.G \alpha_{q}\right)$. Through $G \alpha_{s}$, PTHrP receptor activates adenylate cyclase $(\mathrm{AC})$ and the production of $3^{\prime}, 5^{\prime}$-adenosine monophosphate (cAMP), which in turn activates protein kinase A (PKA) $[27,36]$. On the other hand, stimulation of $G \alpha_{q}$ activates phospholipase $C \beta$ (PLC $\left.\beta\right)$ and the formation of diacylglycerol (DAG) and 1,4,5-inositol triphosphate (IP3). DAG activates in turn proteinase kinase $\mathrm{C}$ (PKC), while the production of IP3 leads to an increase of intracellular $\mathrm{Ca}^{2+}[37,38]$.

These two signaling pathways have opposite actions on chondrocyte differentiation (Figure 1B). PTHrP uses AC/cAMP/PKA pathway to keep chondrocyte proliferating and to promote the activation of the transcriptor factor $\mathrm{SOX} 9$, that restrains chondrocyte differentiation [39-41]. In addition, PKA inhibits the expression of the myocyte enhancer factor 2 (MEF2) and of RUNX2, two key transcription factors promoting chondrocyte hypertrophy via the recruitment of the class II histone deacetylase HDAC4 in the nucleus [42]. In contrast, PLC/IP3 signaling via the PTH/PTHrP receptor appears to restrain proliferation of chondrocytes and to stimulate their progression toward hypertrophic differentiation [43]. $\mathrm{PTHrP}$ is also produced by early osteoblast precursors and actively synthetizing osteoblasts. It has been showed that periosteum-derived PTHrP induced osteoblast activity and bone formation [44-46].

The critical role of PTHrP receptor in bone development is highlighted by the discovery of two severe chondrodysplasias: Blomstrand lethal chondrodysplasia and metaphyseal chondrodysplasia Jansen type. Inactivating recessive PTHR1 mutations in Blomstrand dysplasia cause prenatal lethality, shortened limbs, advanced bone mineralization and increased bone density due to reduction of proliferating and resting chondrocytes within the growth plate $[47,48]$. Metaphyseal chondrodysplasia Jansen type, meanwhile, is caused by activating mutations that lead to ligand-independent activation of PTHR1 and of the cAMP pathway. This causes a phenotype characterized by severe abnormalities of the growth plate, short-limbed dwarfism, micrognatia and hypercalcemia [49]. Interestingly, a homozygous truncating mutation in PTHR1 has been identified in Eiken dysplasia, a disorder with opposite phenotype compared to Blomstrand dysplasia. Patients with Eiken dysplasia show severely delayed skeletal maturation, as well as mild growth retardation [50]. These findings demonstrate that distinct recessive mutations in the same gene can generate contrasting phenotypes. Another connection between human genetic bone disorder and PTHrP signaling is shown in brachydactyly type E, caused by loss-of-function mutations in parathyroid hormone-like hormone (PTHLH), a PTHR1 ligand, and characterized by bone shortening of hands and feet [51]. A more severe brachydactyly phenotype is also found in acrodysostosis, in association with facial dysostosis, nasal hypoplasia and developmental delay. This disease is caused by mutations in PRKAR1A, which is the type 1 regulatory subunit of PKA or mutations in phosphodiesterase 4 (PDE4D), both causing an impaired PKA activation [52,53]. Furthermore, inactivating mutations in the maternal allele of GNAS gene, coding for the binding protein $\mathrm{G} \alpha_{\mathrm{s}}$, cause Pseudohypoparathyroidism type IA, also known as Albright hereditary osteodystrophy (AHO) [54,55]. This disease is characterized by short stature, subcutaneous ossifications and brachydactyly, and is associated with PTH resistance. If the same mutations are inherited from the father, the AHO phenotype occurs without hormone resistance [56]. It has been proposed that the defective $\mathrm{G} \alpha_{\mathrm{s}}$-mediated hypertrophy inhibition could result in promotion of the $\mathrm{G} \alpha_{\mathrm{q}}$-mediated chondrocytes' hypertrophy, leading to premature growth plate closure and favoring short stature. 
On the other hand, McCune-Albright syndrome or isolated fibrous dysplasia (FD) of bone is caused by gain-of-function mutations in distinct sites of the GNAS gene compared to AHO $[57,58]$. These mutations cause overproduction of cAMP in a ligand-independent manner in osteogenic cells. This leads to the accelerated production of bone marrow stromal cells, while inhibiting the differentiation of these progenitors into mature osteoblasts [59]. These immature cells lead to under-mineralized bone with disrupted micro-architecture. Finally, deletions of the chromosomal region 2q37, which include the HDAC4 gene, cause brachydactyly-mental retardation syndrome characterized by brachydactyly type E, craniofacial abnormalities and intellectual disabilities [60].

\section{Wingless and Int-1}

WNT is a complex regulator of skeletal development. Until now, three different WNT pathways have been identified: one canonical pathway, the $\mathrm{WNT} / \beta$-catenin, and two non-canonical pathways, the WNT/planar cell polarity (PCP) and the WNT/Ca ${ }^{2+}$. All these signaling pathways are activated by the binding of extracellular WNT ligands to one of the seven-pass transmembrane Frizzled (FZD) receptors. Depending on the pathway, the activation occurs with or without specific co-receptors like lipoprotein-related protein (LRP) or receptor tyrosine kinase-like orphan receptors (ROR) [61,62]. In the canonical pathway, WNT ligands bind the receptor complex formed by LRP5/6 and FZD. This activation causes the translocation of $\beta$-catenin in the nucleus where it activates WNT target genes controlling proliferation and differentiation. When WNT is absent, $\beta$-catenin is bound in a complex composed by glycogen synthase kinase $3 \beta$ (GSK3 $\beta$ ), axin and adenomatosis polyposis coli (APC) and degraded by proteasome. In the non-canonical PCP pathway, Jun kinase (JNK) is activated via disheveled (DVL) and the RAC and Rho small GTPases. Finally, in the non-canonical WNT/ $\mathrm{Ca}^{2+}$ pathway, WNT binds to FZD receptors and ROR causing the intracellular $\mathrm{Ca}^{2+}$ release and the activation of some calcium-sensitive enzymes. More downstream, this event activates the nuclear factor of activated T cells (NF-AT), which translocates to the nucleus and induces specific gene expressions. WNT signaling pathways play a central role in bone development regulating chondrocyte and osteoblast differentiation (Figure 2A).

WNTs secreted by the ectoderm act via a $\beta$-catenin-dependent pathway. It blocks the cartilage formation in limb bud mesenchymal cells, by inhibiting SOX9 expression through a repressive chromatin mark (H3K27me3) and DNA methylation over the SOX9 promoter [63]. The inactivation of $\beta$-catenin causes an increase of SOX9 expression, leading to a decreased chondrocyte proliferation and a delayed hypertrophic maturation. In addition, the PCP pathway plays a unique role in inducing chondrocyte column formation in the growth plate $[64,65]$. WNT can also promote chondrocyte hypertrophy by inhibiting PTHrP activity [43]. Some members of the WNT family, such as WNT5A and WNT5B, regulate the transition of chondrocytes to hypertrophy in the growth plate. It has been shown, that the absence of WNT5A delays chondrocyte hypertrophy and that a proper level of WNT5A/B signaling is required for the normal transition of chondrocytes to hypertrophy $[66,67]$. Some WNT proteins inhibit chondrogenesis from mesenchymal stem cells (MSC), favoring osteoblastogenesis. WNT has a primary role in osteoblast differentiation, since the activation of the $\beta$-catenin pathway is essential to allow the differentiation of mesenchymal progenitors in mature osteoblasts. Several studies confirm that WNT activation and inhibition correspond to the increase and the decrease of the bone mass, respectively [68-71]. 


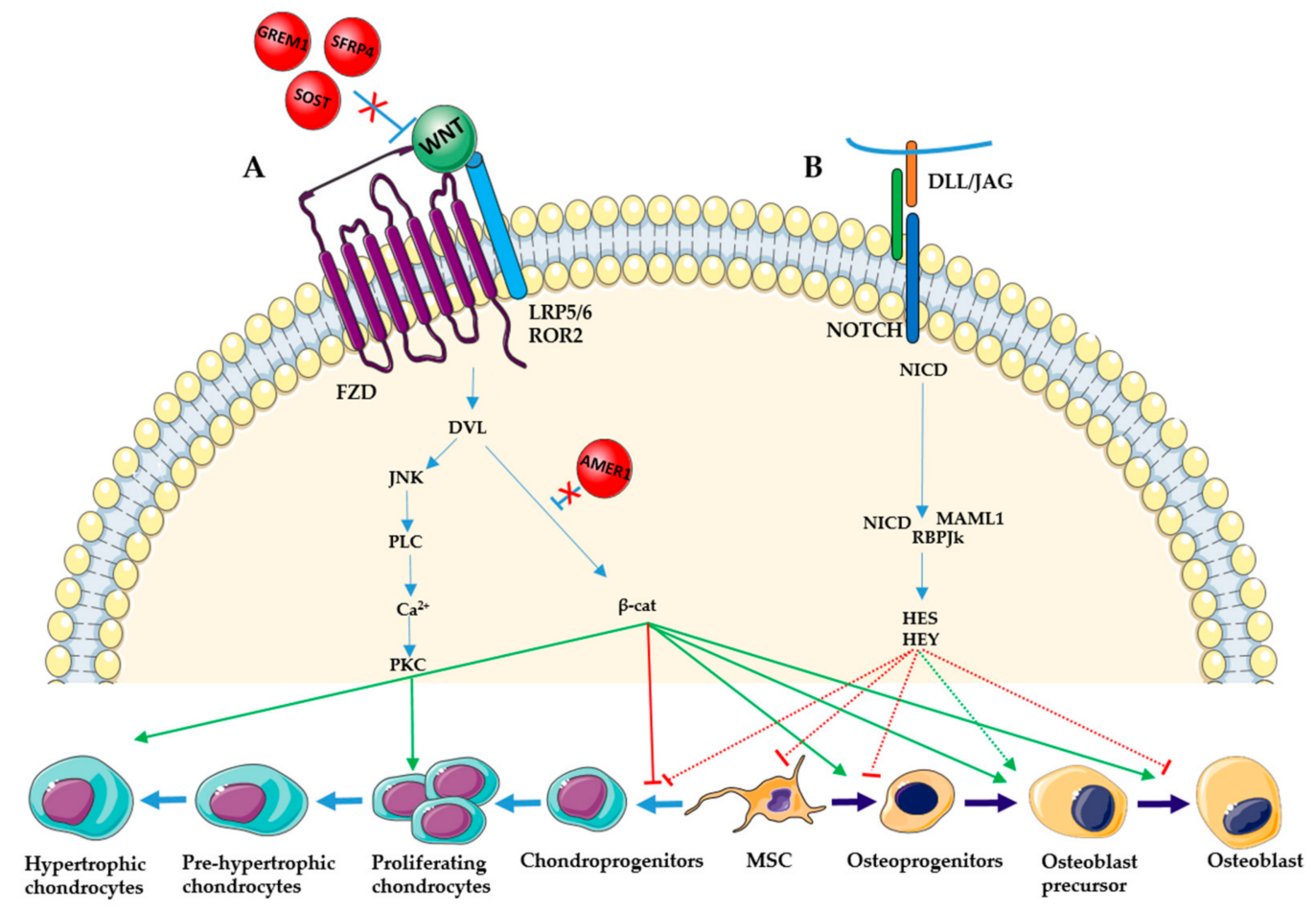

Figure 2. WNT and NOTCH signaling pathways in chondrocyte and osteoblast differentiation. (A) WNT ligands bind to the FZD receptors with or without specific co-receptors like LRP5, LRP6 and ROR2. In the canonical pathway, WNT binding activates the translocation of $\beta$-catenin in the nucleus. This inhibits the first step of chondrogenesis but induces the chondrocyte hypertrophic differentiation and osteoblast differentiation and maturation. The non-canonical pathways, through the activation of DVL, JNK and PLC proteins, activate PKC and induce chondrocyte proliferation. WNT signaling can be negatively regulated by extracellular inhibitors, such as SOST, GREM1 and SFRP4, and by intracellular inhibitors, like AMER1. (B) In the NOTCH pathways, DLL or JAG ligands bind to $\mathrm{NOTCH}$ receptor and cause consequent proteolytic cleavages resulting in the release of NICD which translocate in the nucleus and interact with MAML1 and RBPJk proteins. NOTCH signaling inhibits chondrogenesis, and the first and the last stages of osteoblast differentiation, but promotes the differentiation of osteoprogenitors in osteoblast precursors.

WNT ligands consist of 19 different cysteine-reach secreted glycoproteins. Several of them have been associated with SD. For example, loss-of-function mutations in WNT1, involved in the canonical pathway, are responsible for osteogenesis imperfecta (OI) type $\mathrm{XV}$ and for early onset osteoporosis [72]. Loss-of-function of WNT3, playing an essential role in axis formation and limb growth, causes tetra-melia syndrome type 1 , consisting on the absence of all four limbs [73]. The WNT5A gene, involved in the WNT/PCP non canonical pathway, is linked to the autosomal dominant form of Robinow syndrome (RS) type 1 [74]. Mutations in WNT6 have been identified in acro-pectoro-vertebral dysplasia (Fsyndrome) and mutations in WNT7A gene, involved in limb development and contributing to anteroposterior patterning, have been identified Al-Awadi-Raas-Rothscild syndrome and Fuhrmann syndrome. Finally, mutations in the WNT10B gene, a key regulator of osteogenesis, playing an important role in the development of hands and feet, cause splithand/foot malformation type 6 [75-78]. Mutations have been also identified in WNT receptors and co-receptors: with FZD2, being associated with omodysplasia type 2; ROR2 with autosomal dominant brachydactyly type 1 , or autosomal recessive RS type 1; and LRP4 with sclerostosis type 2 and Cenani-Lenz syndrome. Interestingly, mutations in the co-receptor LRP5 result in opposite bone mass phenotype. Loss-of-function mutations in LRP5 lead to decreased binding of WNT ligands and decreased WNT signaling activity causing osteoporosis. In contrast, other specific mutations in LRP5 affecting the binding of Dickkopf-1, an inhibitor of WNT signaling, result in gain-of-function of LRP5 and in 
osteosclerosis [79-88]. Extracellular WNT inhibitors and activators play also a significant role in bone homeostasis and development. This is demonstrated by the identification of mutations in the WNT inhibitor SOST disrupting the ability of SOST to link with LRP co-receptors. This generates an increased WNT signaling and an increased bone mass like in sclerosteosis type 1, Van Buchem diseases and craniodiaphyseal dysplasia. Furthermore, Cenani-Lenz-like non-syndromic bilateral oligosyndactyly and Pyle disease have been associated with mutations in the WNT inhibitors GREM1 and SFRP4 respectively. Loss-offunction mutations in AMER1 (or WTX), an intracellular inhibitor of WNT are responsible for X-linked osteopathia striata with cranial sclerosis [89]. Finally, Keipert syndrome and tetra-amelia syndrome are caused by loss-of-function mutations in the WNT activators GPC6 and RSPO2, respectively [78].

The discovery and the understanding of all these diseases showed how WNT signaling is essential to regulate bone density in humans, since its hyperactivation causes skeletal diseases characterized by high-bone mass phenotype, while its inhibition causes decreased bone formation. Furthermore, it explains why WNT is used as therapeutic target to improve bone mass in patients affected by skeletal diseases such as osteoporosis or osteogenesis imperfecta.

\section{Notch}

Similar to WNT / $\beta$-catenin signaling, Notch signaling also suppresses chondrogenesis through four NOTCH receptors (NOTCH1-4) and at least five ligands (two members of the Jagged family: Jag1 and Jag2 and three members of the Delta-like family: Dll1, Dll3, and Dl14) [90]. In the canonical Notch pathway, the ligands bind to the NOTCH receptors present on the adjacent cell surface. This triggers one first proteolytic cleavage generating a Notch Extracellular Truncation (NEXT) and a consequent proteolytic cleavage mediated by the $\gamma$-secretase complex, composed by Presenilin 1 and 2. This cleavage results in the release of the Notch Intracellular Domain (NICD) in the cytoplasm [91,92]. NICD translocates into the nucleus where it forms a complex with the transcription factor CSL (C promoter-binding factor 1, Suppressor of Hirless and Lag1), also known as RBPJk, and the transcriptional coactivator Mastermind-like 1 (MAML1). This ternary complex activates the expression of transcription factors of the families Hairy Enhancer of Split (HES 1, 4, 5, 6 and 7) and Hes related with YRPW motif (HEY 1, 2 and L) [93]. Multiple NOTCH ligands and receptors are expressed in the prechondrogenic mesenchyme and inhibit both mesenchymal condensation and subsequent chondrocyte differentiation (Figure 2B) $[94,95]$. This occurs when Hey and Hes transcription factors are activated and bind to SOX9 enhancer and suppress the SOX9 gene expression, which is essential for chondrocyte differentiation $[96,97]$.

Notch signaling is also critical for axial skeleton segmentation during somitogenesis $[98,99]$. Defective somitogenesis, due to abnormal Notch signaling, cause Spondylocostal dysostosis and vertebral segmentation defect characterized by vertebrae and ribs anomalies with consequent trunk dwarfism $[100,101]$. These pathologies have been associated with mutations in different components of Notch signaling, such as DLL3, HES7, Mesoderm Posterior (MESP) 2, a Notch target gene, and Lunatic Fringe (LFNG), a member of the Fringe family, involved in the post-translational modifications of NOTCH receptors [102-105].

In parallel, Notch signaling acts upstream of RUNX and regulates the osteochondroprogenitor cell proliferation and lineage specification [106]. Depending on the osteoblast differentiation stage, Notch signaling can promote or inhibit the process [107]. In the early stage of osteoblastogenesis, the Hey transcriptional factors, downstream of RBPjK, inhibit the Runx 2 expression and, in consequence, prevent the differentiation of osteochondroprogenitor cells into perichondral cells $[108,109]$. Meanwhile, during the intermediate stage, the expression of NCID promotes proliferation and the differentiation of perichondral cells into preosteoblasts. Finally, in the late stage, Notch inhibits the preosteoblast differentiation in mature osteoblasts [110]. To resume, Notch signaling inhibits the early and 
late stage of osteoblastogenesis but promotes the intermediate stage. Consistent with this description, gain-of-function mutations in $\mathrm{NOTCH} 2$, the major receptor involved in the chondrocyte and osteoblast differentiation, are responsible for Hadju-Cheney syndrome, a disorder characterized by focal bone lysis of distal phalanges, progressive bone loss and fractures $[111,112]$. Loss-of-function mutations in NOTCH1, RBPJ and DLL4 are responsible for Adams Oliver syndrome, a congenital condition characterized by aplasia cutis congenita of the scalp and transverse limb defects [113,114].

Since the Notch pathway can have different roles depending on the cell differentiation stage, it could be very difficult to target this pathway for therapies.

\section{Transforming Growth Factor-Beta and Bone Morphogenetic Protein}

The TGF- $\beta$ superfamily is a group of more than 40 members including 3 TGF- $\beta$ proteins (TGF- $\beta 1$, TGF- $\beta 2$ and TGF- $\beta 3$ ), and 14 BMPs, Activins and Growth and Differentiation Factors (GDFs) [115]. It is involved in two principal pathways, TGF- $\beta$ and BMP signaling. In both cases, the binding of the TGF- $\beta$ superfamily ligands to a heteromeric serine/threonine receptor ligand complex formed by two type I (TGFBRI, BMPRI or ALK) and two type II receptors (TGFBR2 or BMPR2) causes the autophosphorylation of type II receptors. This in turn phosphorylate type I receptors and the regulatory Smad transcription factors (R-SMADS). These R-SMADS form a complex with the coregulatory Smad (Co-SMAD), SMAD4, which accumulates in the nucleus and regulates gene transcription $[116,117]$. TGF- $\beta$ signaling mostly involves SMAD 2 and 3 proteins, whereas BMP signaling is principally mediated by SMAD 1,5 , and 8 . As an alternative to the SMADmediated canonical pathways, TGF- $\beta$ and BMP also activate p38 MAPK family cascade through non-canonical pathways. TGF- $\beta$, BMPs and their receptors play a relevant role in all stages of bone development (Figure 3A,B).

This has been demonstrated by studying several conditional knockout mouse models for TGF- $\beta$, its receptors and SMAD proteins. All these models are characterized by an impairment of endochondral and intramembranous bone formation [118].

During chondrogenesis, BMP and TGF- $\beta$ signaling are required for the expression and maintenance of SOX9 and, in consequence, for the formation of chondrogenic mesenchymal condensations. TGF- $\beta$, BMPs and their receptors are also expressed in proliferating chondrocytes and hypertrophic chondrocytes and regulate chondrocyte proliferation and differentiation. In particular, TGF- $\beta$ promotes the condensation and differentiation of mesenchymal cells, induces chondrocyte proliferation, but inhibits terminal chondrocyte differentiation $[119,120]$. On the contrary, BMP signaling is not essential for the mesenchymal condensation, but is indispensable for mesenchymal cell differentiation and for chondrocyte proliferation and maturation [121,122].

In osteoblastogenesis, TGF- $\beta$ promotes expansion and proliferation of osteoprogenitors, early differentiation and commitment to the osteoblastic lineage through the MAPKs and SMAD 2/3 pathways. Conversely, it prevents the terminal osteoblast differentiation [123]. Activating mutations in the genes coding for the ligand TGF- $\beta 2$ and 3 , for the TGF- $\beta$ receptors (TGFBR1 or TGFBR2), and for the intracellular SMAD2 and 3 have all been associated with the Loeys-Dietz syndrome, an autosomal dominant condition characterized by skeletal deformities and bone overgrowth [124]. Mutations in the gene coding for the ligand TGF- $\beta 1$ and causing the hyperactivation of the TGF- $\beta$ signaling are responsible for the Camurati-Engelmann disease, characterized by increased bone density [125,126].

Focusing on BMP signaling, genetic studies have shown that several BMPs, such as BMP-2, 4, 5, 6 and 7 have strong osteogenic capacity [127]. In particular, BMP-2, with the coordinated help of BMP-4, controls the transition from RUNX2- to OSX- positive osteoblasts. On the other hand, BMP-7 promotes the expression of osteoblast differentiation markers as ALP activity and enhances calcium mineralization. Its absence in postnatal bones can be compensated by the others BMPs. Instead, BMP-3 inhibits skeletal progenitor cell differentiation to mature osteoblasts and regulates adult bone mass [118]. 


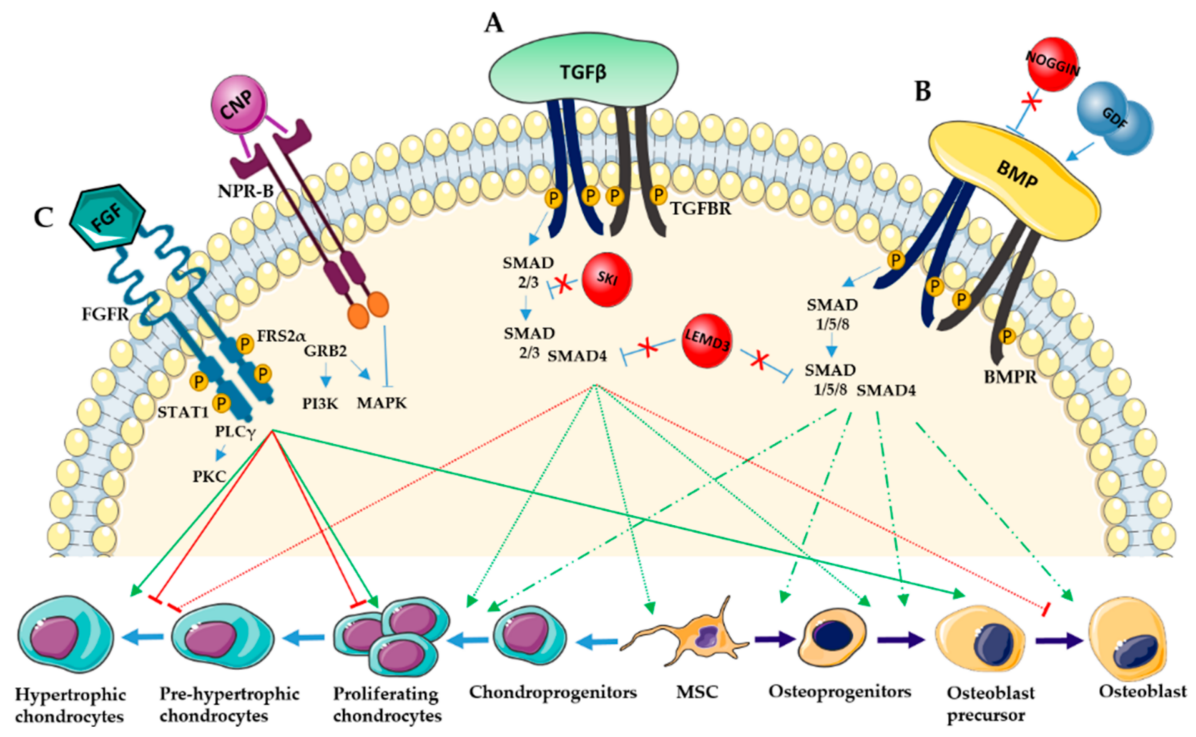

Figure 3. TGF $\beta, B M P$ and FGF signaling pathways in chondrocyte and osteoblast differentiation. (A) TGF- $\beta$ ligands bind to TGFBR type 1 and 2 causing the phosphorylation of the receptors and of SMAD 2 and 3 proteins which interact with SMAD4. This complex accumulates in the nucleus and induces chondrogenesis and osteoblastogenesis but inhibits the last step of chondrocyte and osteoblast maturation. SMAD activity can be blocked by intracellular inhibitors like SKI and LEMD3. (B) BMP ligands bind to BMPR type 1 and 2 causing the phosphorylation of the receptors and of SMAD 1, 5 and 8 proteins which interact with SMAD4. This complex accumulates in the nucleus and induces chondrocyte proliferation and all the steps of osteoblast differentiation. GDF ligands and the NOGGIN antagonist also bind BMPR. (C) FGF ligands bind FGFR causing receptor transphosphorylation, the phosphorylation of the adaptor protein FRS2 $\alpha$ and the activation of STAT1, PLC $\gamma$ and GRB2. GRB2 in turn activates PI3K and MAPK proteins. Through these pathways, FGF promotes chondrocyte proliferation and differentiation in the first step of the development and it promotes osteoblast proliferation and differentiation. In contrast, in the later stages of development, it inhibits chondrocyte proliferation and differentiation. MAPK signaling, downstream of FGFR, can be negatively regulated by the CNP-NPR pathway.

In humans, activating mutations in one of the Type I receptors, the Activin receptor IA/Activin-Like kinase 2 (ACVR1/ALK2), cause Fibrodysplasia ossificans progressive (FOP), a rare disease characterized by heterotopic endochondral ossification, through an increased BMP Smad-dependent and non-canonical p38 MAPK signaling activity [128]. Mutations in BMPR1 (or ALK6), which is specifically expressed during chondrogenesis and osteoblastic differentiation, cause brachydactyly type A2 and acromesomelic dysplasia. Both diseases have been also associated with loss-of-function mutations in GDF5 [129]. Patients with these diseases have normal axial skeletons but missing or fused distal elements in hands and feet. These discoveries highlighted the importance of BMP signaling in distal limb patterning. Disruptions of the BMP pathway also causes abnormal axial skeletal patterning. GDF6, a close relative to GDF5, is associated with Klippel-Feil syndrome causing bone fusions [130]. Gain-of-function mutations in SMAD4, the only common SMAD for both TGF- $\beta$ and BMP signaling, results in Myhre syndrome, characterized by short stature, facial dysmorphism, stiff joints and brachydactyly [131].

The TGF- $\beta$ /BMP signaling is also negatively regulated by several mechanisms: intracellular antagonists, like SMAD 6 and 7; the inner nuclear membrane protein LEMD3 and the SKI protein influencing the SMAD signaling; extracellular ligand antagonists, like NOGGIN and BMPER; intracellular ubiquitin ligases and transcriptional repressors. Over-expression of NOGGIN causes osteopenia, fractures and multiple synostoses syndrome, consisting of facial dysmorphism, craniosynostosis and multiple joint fusion [132]. Heterozygous missense mutations in the antagonist NOGGIN, leading to an increased 
inhibitory activity, also result in brachydactyly type B [133]. Mutations in BMPER cause diaphanospondylodysostosis characterized by craniofacial anomalies and vertebral segmentation [134]. Moreover, loss-of-function mutations in the LEMD3 gene are associated with osteopoikilosis with and without melorheostosis, characterized by multiple round foci of increased bone density and hyperostosis respectively [135]. Finally, loss-of-function mutations in the SKI protein, which inhibits SMAD2/3 activation, are responsible for Shprintzen Goldberg Syndrome, characterized by marfanoid habitus and craniosynostosis [136].

As mentioned in this paragraph, numerous human SD are related to TGF- $\beta$ /BMP signaling pathways confirming their essential role in bone development. In particular, it seems that increased TGF- $\beta$ signaling can result in either increased bone formation or craniosynostosis. Indeed, the clinical consequences depend on tissue-specificity expression of the mutant allele and on the interaction with other signaling pathways. On the other hand, impaired BMP signaling mostly causes distal and axial skeletal defects, demonstrating a prominent role of BMP in chondrocyte differentiation and establishment of joint boundaries.

\section{Fibroblast Growth Factor}

Fibroblast growth factors (FGFs) are a large family of 18 or more proteins which mostly bind to four cell surface tyrosine kinase FGF receptors (FGFR 1-4). This binding induces the dimerization of the receptor tyrosine kinase domains and their sequential trans-phosphorylation [137]. Consequently, it promotes the phosphorylation of the adaptor proteins FGFR substrate $2 \alpha$ (FRS2 $\alpha$ ) and the recruitment of other adaptor proteins like signal transducer and activation of transcription1 (STAT1), phospholipase $\gamma$ (PLC $\gamma$ ) and the guanine nucleotide exchange factor GRB2. These proteins activate multiple signaling pathways, including JAK-STAT, proteinase kinase $\mathrm{C}(\mathrm{PKC})$, mitogen-activated protein kinase (MAPK) and phosphoinositide 3-kinase (PI3K), [138].

FGFs and their receptors are expressed during all stages of the bone development in a time- and space-dependent manner. For example, FGFR1 is expressed during mesenchymal condensation, in perichondrium and periosteum and in hypertrophic chondrocytes of the growth plate [139]. FGFR2 is initially expressed at high levels in condensed mesenchyme and then in perichondrium and periosteum [140]. FGFR3 is expressed in proliferative chondrocytes in the growth plate and, when it binds to its ligands FGF9 or FGF18, it promotes chondrocyte proliferation and the initial chondrocyte hypertrophy during the early stages of development $[141,142]$. On the contrary, it inhibits chondrocyte proliferation and hypertrophy in the later stages of development (Figure 3C) [143-145].

FGF signaling is fundamental also in intramembranous ossification and in the regulation of all steps of osteoblastogenesis. In particular, FGFR1 is expressed in calvaria mesenchyme and later in osteoblasts. During early development, it promotes osteoblast differentiation without affecting RUNX2 expression, while, in mature osteoblasts, it inhibits their mineralization activity [139]. In contrast, FGFR2, expressed in differentiating osteoblasts, promotes the proliferation of preosteoblasts and the anabolic function of mature osteoblasts mostly by up-regulating RUNX2 expression [146,147]. Finally, mice lacking Fgfr3 showed an increase in osteoblast number but a decrease in osteoid mineralization [148].

Mutations in FGFRs cause human skeletal dysplasia with a variable degree of severity. The most common genetic skeletal dysplasia in humans is achondroplasia, a rhizomelic short limb dwarfism characterized by short stature, limited elbow extension and frontal bossing. It is caused by gain-of-function mutations in the FGFR3 gene leading to an overactivation of the FGF signaling [149-151]. Since in the growth plate FGFR3 is predominantly expressed in proliferating and prehypertrophic chondrocytes, these mutations cause a reduced chondrocyte proliferation and an impaired hypertrophic differentiation [152-154]. Related chondrodysplasia syndromes include the milder form of dwarfism, hypochondroplasia, characterized by short stature and increased head circumference [155-157], the 
more severe and lethal forms, thanathophoric dysplasia type I and II, and the severe achondroplasia with developmental delay and acantosis nigricans (SADDAN) $[158,159]$. All these syndromes are caused by gain-of-function mutations in different domains of the FGFR3 protein and the phenotype severity is linked to the degree of FGFR3 activation [153]. On the contrary, inactivation of FGFR3 cause skeletal overgrowth, campodactyly, tall stature and hearing loss (CATSHL) syndrome $[160,161]$ and Lacrimoauriculodentodigital (LADD) syndrome. This last disorder is characterized by micrognatia and variable digit defects, and has been also associated with mutations in FGFR2 [162]. The role of FGFR3 in intramembranous ossification is highlighted by the identification of FGFR3 mutations in craniosynostosis disorders like Crouzon syndrome with acanthosis nigricans and Muenke syndrome $[163,164]$. Craniosynostosis, characterized by premature fusion of cranial sutures due to increased osteoblast proliferation or differentiation, or to increased mineralizing functions of osteoblasts, are also caused by mutations in FGFR1 and FGFR2. Crouzon, Apert, Beare-Stevenson with cutis gyrata, Bent-bone dysplasia, Saethre-Choetzen, JacksonWeiss and Pfeiffer syndromes are all caused by activating mutation in FGFR2 gene and the consequent accelerated osteoblast maturation in the sutures [165-167]. Jackson-Weiss and Pfeiffer syndrome have also been associated with mutation in FGFR1, like the Hartsfield syndrome and the osteoglophonic dysplasia [168-171]. Finally, mutations in genes encoding FGF ligands have also been identified in SD, like FGF9 in multiple synostosis syndrome type 3, FGF10 in LADD and FGF23 in hypophosphatemic rickets [172-174]. In this last disorder, FGF23 overexpression causes defects in osteocytes and abnormal kidney function. This demonstrates that signaling defects can be tissue and organ nonautonomous [175].

During bone development, the FGF signaling can be modulated by C-type natriuretic peptide (CNP) action. When CNP binds to its NPR-B receptor, the MAPK signaling activated by FGFR3 is inhibited (Figure 3C). Similarly, the binding of FGF2 and FGF18 ligands to FGFR reduces CNP action $[176,177]$. CNP is expressed in proliferating and pre-hypertrophic chondrocytes and promotes chondrocyte proliferation and differentiation. Dominant negative and gain-of-function mutations in NPR2, the gene encoding NPR-B, are responsible for short and tall stature phenotype, such as in acromesomelic dysplasia type Maroteaux and tall stature with long halluces type NPR2, respectively $[178,179]$. These studies suggest that CNP signaling promotes chondrocytes proliferation during bone development and that it acts as a negative cross talk between FGF and MAPK. For this reason, recombinant analogues of CNP are used as promising therapy for achondroplasia.

\section{Transcription Factors}

\section{1. $5 O X 9$}

SOX9 is a transcription factor of the SRY family that regulates sex determination and developmental events like cartilage development. SOX9 is the earliest nuclear factor required for chondrogenesis. It is initially expressed in mesenchymal condensations of the early skeletal precursors. It is dispensable for the initial mesenchymal condensation, but crucial for the subsequent chondrocyte differentiation. In fact, in its absence, chondrogenesis is blocked. In the growth plate, SOX9 is expressed at highest levels in proliferating and prehypertrophic chondrocytes and less expressed in chondrocytes undergoing hypertrophy $[2,180]$. SOX9 directly activates chondrocyte differentiation markers like collagen type II. It also induces the expression of SOX5 and SOX6 working with SOX9 to activate the chondrocyte differentiation [181]. In addition, SOX9 expression sustains chondrocyte survival through PI3K-AKT pathway and maintains proliferation of columnar chondrocytes. It also prevents the entering of columnar chondrocytes in the prehypertrophic stage and promotes the subsequent hypertrophy [182]. SOX9 represses the initial chondrocyte maturation through the interaction with $\beta$-catenin and its consequential disruptions. This leads to the inhibition of the WNT pathway, a promoter of chondrocyte hypertrophy $[183,184]$. SOX9 can also directly interact and block the activity of RUNX2 (discussed below), one of the main transcription factors involved in chondrocyte maturation and osteoblastogenesis. Finally, SOX9 regulates the gene expression of specific markers for hypertrophic 
chondrocytes, like collagen type $X$ and Vegfa [182,185-187]. SOX9 plays an important role in the developing axial skeleton and maintains the notochord and the demarcation of intervertebral disc compartments. Heterozygous loss-of-function mutations in SOX9 gene have been associated with campomelic dysplasia, an autosomal dominant skeletal dysplasia characterized by hypoplastic scapulae, progressive disc degeneration, small chest, short long bones with bowing of the lower extremities, Pierre Robin sequence and sex reversal in males [188-190].

\subsection{RUNX2}

RUNX2 is a transcription factor belonging to the RUNX family composed by RUNX1, RUNX2 and RUNX3 [191]. RUNX2 is essential for both intramembranous ossification and endochondral ossification during skeletogenesis. It is involved principally in chondrocyte and osteoblast differentiation and in the regulation of extracellular matrix protein expression during these processes. It is initially expressed within the chondrogenic mesenchyme, subsequent to and dependent on SOX9 expression [192]. During endochondral bone development, RUNX2 is weakly expressed in proliferative chondrocytes and highly expressed in prehypertrophic chondrocytes until terminal hypertrophic chondrocytes and in perichondrium $[193,194]$. It regulates chondrocyte hypertrophy by driving the expression of collagen type $X$ in hypertrophic chondrocytes, of matrix metallopeptidase 13 (MMP13) in terminal hypertrophic chondrocytes and also by interacting with BMP-regulated SMADs [195-198]. Moreover, RUNX2 controls chondrocyte maturation, enhancing FGF18 expression in the perichondrium [199]. In endochondral and intramembranous bones, RUNX2 is strongly detected in osteoblast progenitors, immature and early mature osteoblasts. It is required for osteoblast progenitor proliferation, their differentiation into osteoblasts, and for the proper function of the mature osteoblasts [200-202]. Haploinsufficiency of RUNX2 causes cleidocranial dysplasia, characterized by short stature, delayed closure of fontanelles, prominent forehead, drooping shoulders and abnormal dental development. The distinctive radiological features are shortened or absent clavicles, delayed ossification of the skull bones, and delayed ossification of pelvic bones [203,204]. On the other hand, duplications of the RUNX2 gene are associated with metaphyseal dysplasia with maxillary hypoplasia, characterized by metaphyseal flaring of long bones, enlargement of the medial halves of the clavicles, maxillary hypoplasia, and dystrophic teeth $[205,206]$.

\subsection{OSX}

OSX, a transcription factor containing three $\mathrm{C} 2 \mathrm{H} 2$-type zinc fingers, controls the genetic program of osteoblast differentiation and bone formation. Expression of OSX in osteoblast precursors induces the differentiation of these cells into mature and functional osteoblasts and, then, into osteocytes $[207,208]$. OSX can also be a negative regulator of chondrocyte differentiation. In fact, when OSX is expressed in RUNX2-positive cells, the expression of SOX9 is down-regulated and the cells exist as osteoblast precursors. Then RUNX2/OSX-positive cells differentiate into mature osteoblasts, in which SOX9 is not expressed. This means that without the expression of OSX, the RUNX2-positive precursors do not progress into the preosteoblast stage but, instead, they remain in the chondrogenic stage [209]. OSX also plays an important role in extracellular matrix calcification by activating MMP13 expression in hypertrophic chondrocytes [210]. A homozygous mutation in the OSX gene has been identified in a patient with a moderate form of osteogenesis imperfecta, presenting with bone fractures, mild bone deformities and delayed tooth eruption. This confirms the importance of a proper OSX expression for bone health [211].

\section{Conclusions}

In this review, we discussed the main signaling pathways involved in bone development and how mutations in their components have been associated with SD. It is important to highlight that even if the signaling pathways have been discussed independently, there is a complex cross-talk among them at multiple levels. This, in association with the evidence 
that the mutation consequences depend on the specificity of the mutations and on their temporal and spatial mode of action, makes more difficult the understanding of the physiopathological mechanisms of these diseases. Moreover, these signaling pathways can be secondarily affected by alterations in other cellular processes, such as extracellular matrix regulation or metabolic processing. Indeed, several skeletal dysplasia, that we decided to omit in this review, have been associated with mutations in these processes. Fortunately, in the last decade, the development of new technologies, like whole exome and genome sequencing has accelerated the identification of skeletal dysplasia-causing mutations. On the other hand, the development of CRISPR-Cas9 technology and of several mouse models is helping the deciphering of the physiopathological mechanisms. Advanced genetic testing is also helping the diagnosis of skeletal dysplasia. The diagnosis and management of these pathologies have long been based on clinical feature and skeletal imaging. Today, these key techniques are increasingly combined with the genetic testing in order to obtain a more accurate and early diagnosis of SD. It also aids in prognosis and in counselling families regarding genetic recurrence risk and preconceptional reproductive planning [212-214]. These continuous discoveries will help to expand the genotype-phenotype correlation of $\mathrm{SD}$ and to develop new therapeutic strategies. Nowadays, few treatments are available for SD, but several clinical trials are ongoing to validate new drugs targeting specifically these pathways in achondroplasia or FOP for example, and highlighting the importance of multidisciplinary cross talks (from bed to bench side) [215].

Author Contributions: A.G. and V.C.-D. have both contributed to the writing of the manuscript. All authors have read and agreed to the published version of the manuscript.

Funding: The author(s) received no financial support for the research, authorship, and/or publication of this article.

Institutional Review Board Statement: Not applicable.

Informed Consent Statement: Not applicable.

Data Availability Statement: Not applicable.

Conflicts of Interest: The authors declare no conflict of interest.

\section{References}

1. Opperman, L.A. Cranial Sutures as Intramembranous Bone Growth Sites. Dev. Dyn. 2000, 219, 472-485. [CrossRef]

2. Kozhemyakina, E.; Lassar, A.B.; Zelzer, E. A Pathway to Bone: Signaling Molecules and Transcription Factors Involved in Chondrocyte Development and Maturation. Development 2015, 142, 817-831. [CrossRef] [PubMed]

3. Long, F.; Ornitz, D.M. Development of the Endochondral Skeleton. Cold Spring Harb. Perspect. Biol. 2013, 5, a008334. [CrossRef]

4. Mortier, G.R.; Cohn, D.H.; Cormier-Daire, V.; Hall, C.; Krakow, D.; Mundlos, S.; Nishimura, G.; Robertson, S.; Sangiorgi, L.; Savarirayan, R.; et al. Nosology and Classification of Genetic Skeletal Disorders: 2019 Revision. Am. J. Med. Genet. 2019, 179, 2393-2419. [CrossRef]

5. Ingham, P.W. Hedgehog Signaling in Animal Development: Paradigms and Principles. Genes Dev. 2001, 15, 3059-3087. [CrossRef] [PubMed]

6. Briscoe, J.; Thérond, P.P. The Mechanisms of Hedgehog Signalling and Its Roles in Development and Disease. Nat. Rev. Mol. Cell. Biol. 2013, 14, 416-429. [CrossRef]

7. Pan, A.; Chang, L.; Nguyen, A.; James, A.W. A Review of Hedgehog Signaling in Cranial Bone Development. Front. Physiol. 2013, 4, 61. [CrossRef]

8. Chiang, C.; Litingtung, Y.; Lee, E.; Young, K.E.; Corden, J.L.; Westphal, H.; Beachy, P.A. Cyclopia and Defective Axial Patterning in Mice Lacking Sonic Hedgehog Gene Function. Nature 1996, 383, 407-413. [CrossRef] [PubMed]

9. Fan, C.M.; Porter, J.A.; Chiang, C.; Chang, D.T.; Beachy, P.A.; Tessier-Lavigne, M. Long-Range Sclerotome Induction by Sonic Hedgehog: Direct Role of the Amino-Terminal Cleavage Product and Modulation by the Cyclic AMP Signaling Pathway. Cell 1995, 81, 457-465. [CrossRef]

10. $\mathrm{Hu}, \mathrm{D}$. A Zone of Frontonasal Ectoderm Regulates Patterning and Growth in the Face. Development 2003, 130, 1749-1758. [CrossRef]

11. Jeong, J.; Mao, J.; Tenzen, T.; Kottmann, A.H.; McMahon, A.P. Hedgehog Signaling in the Neural Crest Cells Regulates the Patterning and Growth of Facial Primordia. Genes Dev. 2004, 18, 937-951. [CrossRef] [PubMed]

12. Riddle, R.D.; Johnson, R.L.; Laufer, E.; Tabin, C. Sonic Hedgehog Mediates the Polarizing Activity of the ZPA. Cell 1993, 75, 1401-1416. [CrossRef] 
13. Karp, S.J.; Schipani, E.; St-Jacques, B.; Hunzelman, J.; Kronenberg, H.; McMahon, A.P. Indian Hedgehog Coordinates Endochondral Bone Growth and Morphogenesis via Parathyroid Hormone Related-Protein-Dependent and -Independent Pathways. Development 2000, 127, 543-548.

14. Kobayashi, T.; Chung, U.-I.; Schipani, E.; Starbuck, M.; Karsenty, G.; Katagiri, T.; Goad, D.L.; Lanske, B.; Kronenberg, H.M. PTHrP and Indian Hedgehog Control Differentiation of Growth Plate Chondrocytes at Multiple Steps. Development 2002, 129, $2977-2986$. [PubMed]

15. Lanske, B.; Karaplis, A.C.; Lee, K.; Luz, A.; Vortkamp, A.; Pirro, A.; Karperien, M.; Defize, L.H.; Ho, C.; Mulligan, R.C.; et al. PTH/PTHrP Receptor in Early Development and Indian Hedgehog-Regulated Bone Growth. Science 1996, 273, 663-666. [CrossRef]

16. Minina, E.; Wenzel, H.M.; Kreschel, C.; Karp, S.; Gaffield, W.; McMahon, A.P.; Vortkamp, A. BMP and Ihh/PTHrP Signaling Interact to Coordinate Chondrocyte Proliferation and Differentiation. Development 2001, 128, 4523-4534.

17. Vortkamp, A.; Lee, K.; Lanske, B.; Segre, G.V.; Kronenberg, H.M.; Tabin, C.J. Regulation of Rate of Cartilage Differentiation by Indian Hedgehog and PTH-Related Protein. Science 1996, 273, 613-622. [CrossRef]

18. Kobayashi, T.; Soegiarto, D.W.; Yang, Y.; Lanske, B.; Schipani, E.; McMahon, A.P.; Kronenberg, H.M. Indian Hedgehog Stimulates Periarticular Chondrocyte Differentiation to Regulate Growth Plate Length Independently of PTHrP. J. Clin. Investig. 2005, 115, 1734-1742. [CrossRef]

19. St-Jacques, B.; Hammerschmidt, M.; McMahon, A.P. Indian Hedgehog Signaling Regulates Proliferation and Differentiation of Chondrocytes and Is Essential for Bone Formation. Genes Dev. 1999, 13, 2072-2086. [CrossRef]

20. Hilton, M.J.; Tu, X.; Cook, J.; Hu, H.; Long, F. Ihh Controls Cartilage Development by Antagonizing Gli3, but Requires Additional Effectors to Regulate Osteoblast and Vascular Development. Development 2005, 132, 4339-4351. [CrossRef] [PubMed]

21. Long, F.; Chung, U.; Ohba, S.; McMahon, J.; Kronenberg, H.M.; McMahon, A.P. Ihh Signaling Is Directly Required for the Osteoblast Lineage in the Endochondral Skeleton. Development 2004, 131, 1309-1318. [CrossRef]

22. Radhakrishna, U.; Wild, A.; Grzeschik, K.H.; Antonarakis, S.E. Mutation in GLI3 in Postaxial Polydactyly Type A. Nat. Genet. 1997, 17, 269-271. [CrossRef]

23. Hui, C.C.; Joyner, A.L. A Mouse Model of Greig Cephalopolysyndactyly Syndrome: The Extra-ToesJ Mutation Contains an Intragenic Deletion of the Gli3 Gene. Nat. Genet. 1993, 3, 241-246. [CrossRef] [PubMed]

24. Vortkamp, A.; Gessler, M.; Grzeschik, K.H. GLI3 Zinc-Finger Gene Interrupted by Translocations in Greig Syndrome Families. Nature 1991, 352, 539-540. [CrossRef]

25. Kang, S.; Graham, J.M.; Olney, A.H.; Biesecker, L.G. GLI3 Frameshift Mutations Cause Autosomal Dominant Pallister-Hall Syndrome. Nat. Genet. 1997, 15, 266-268. [CrossRef] [PubMed]

26. Fujioka, H.; Ariga, T.; Horiuchi, K.; Otsu, M.; Igawa, H.; Kawashima, K.; Yamamoto, Y.; Sugihara, T.; Sakiyama, Y. Molecular Analysis of Non-Syndromic Preaxial Polydactyly: Preaxial Polydactyly Type-IV and Preaxial Polydactyly Type-I. Clin. Genet. 2005, 67, 429-433. [CrossRef]

27. Gao, B.; Guo, J.; She, C.; Shu, A.; Yang, M.; Tan, Z.; Yang, X.; Guo, S.; Feng, G.; He, L. Mutations in IHH, Encoding Indian Hedgehog, Cause Brachydactyly Type A-1. Nat. Genet. 2001, 28, 386-388. [CrossRef]

28. Klopocki, E.; Lohan, S.; Brancati, F.; Koll, R.; Brehm, A.; Seemann, P.; Dathe, K.; Stricker, S.; Hecht, J.; Bosse, K.; et al. Copy-Number Variations Involving the IHH Locus Are Associated with Syndactyly and Craniosynostosis. Am. J. Hum. Genet. 2011, 88, 70-75. [CrossRef] [PubMed]

29. Bosse, K.; Betz, R.C.; Lee, Y.A.; Wienker, T.F.; Reis, A.; Kleen, H.; Propping, P.; Cichon, S.; Nöthen, M.M. Localization of a Gene for Syndactyly Type 1 to Chromosome 2q34-Q36. Am. J. Hum. Genet. 2000, 67, 492-497. [CrossRef]

30. Hellemans, J.; Coucke, P.J.; Giedion, A.; De Paepe, A.; Kramer, P.; Beemer, F.; Mortier, G.R. Homozygous Mutations in IHH Cause Acrocapitofemoral Dysplasia, an Autosomal Recessive Disorder with Cone-Shaped Epiphyses in Hands and Hips. Am. J. Hum. Genet. 2003, 72, 1040-1046. [CrossRef]

31. Escamilla, M.A.; DeMille, M.C.; Benavides, E.; Roche, E.; Almasy, L.; Pittman, S.; Hauser, J.; Lew, D.F.; Freimer, N.B.; Whittle, M.R. A Minimalist Approach to Gene Mapping: Locating the Gene for Acheiropodia, by Homozygosity Analysis. Am. J. Hum. Genet. 2000, 66, 1995-2000. [CrossRef] [PubMed]

32. Umair, M.; Ahmad, F.; Bilal, M.; Ahmad, W.; Alfadhel, M. Clinical Genetics of Polydactyly: An Updated Review. Front. Genet. 2018, 9, 447. [CrossRef] [PubMed]

33. Lohan, S.; Spielmann, M.; Doelken, S.C.; Flöttmann, R.; Muhammad, F.; Baig, S.M.; Wajid, M.; Hülsemann, W.; Habenicht, R.; Kjaer, K.W.; et al. Microduplications Encompassing the Sonic Hedgehog Limb Enhancer ZRS Are Associated with Haas-Type Polysyndactyly and Laurin-Sandrow Syndrome. Clin. Genet. 2014, 86, 318-325. [CrossRef] [PubMed]

34. Lee, K.; Lanske, B.; Karaplis, A.C.; Deeds, J.D.; Kohno, H.; Nissenson, R.A.; Kronenberg, H.M.; Segre, G.V. Parathyroid HormoneRelated Peptide Delays Terminal Differentiation of Chondrocytes during Endochondral Bone Development. Endocrinology 1996, 137, 5109-5118. [CrossRef] [PubMed]

35. Gardella, T.J.; Jüppner, H. Molecular Properties of the PTH/PTHrP Receptor. Trends. Endocrinol. Metab. 2001, 12, 210-217. [CrossRef]

36. Bringhurst, F.R.; Juppner, H.; Guo, J.; Urena, P.; Potts, J.T.; Kronenberg, H.M.; Abou-Samra, A.B.; Segre, G.V. Cloned, Stably Expressed Parathyroid Hormone (PTH)/PTH-Related Peptide Receptors Activate Multiple Messenger Signals and Biological Responses in LLC-PK1 Kidney Cells. Endocrinology 1993, 132, 2090-2098. [CrossRef] 
37. Iida-Klein, A.; Guo, J.; Takemura, M.; Drake, M.T.; Potts, J.T.; Abou-Samra, A.; Bringhurst, F.R.; Segre, G.V. Mutations in the Second Cytoplasmic Loop of the Rat Parathyroid Hormone (PTH)/PTH-Related Protein Receptor Result in Selective Loss of PTH-Stimulated Phospholipase C Activity. J. Biol. Chem. 1997, 272, 6882-6889. [CrossRef]

38. Swarthout, J.T.; D'Alonzo, R.C.; Selvamurugan, N.; Partridge, N.C. Parathyroid Hormone-Dependent Signaling Pathways Regulating Genes in Bone Cells. Gene 2002, 282, 1-17. [CrossRef]

39. Bastepe, M.; Weinstein, L.S.; Ogata, N.; Kawaguchi, H.; Jüppner, H.; Kronenberg, H.M.; Chung, U. Stimulatory G Protein Directly Regulates Hypertrophic Differentiation of Growth Plate Cartilage in Vivo. Proc. Natl. Acad. Sci. USA 2004, 101, 14794-14799. [CrossRef]

40. Chung, U.I.; Lanske, B.; Lee, K.; Li, E.; Kronenberg, H. The Parathyroid Hormone/Parathyroid Hormone-Related Peptide Receptor Coordinates Endochondral Bone Development by Directly Controlling Chondrocyte Differentiation. Proc. Natl. Acad. Sci. USA 1998, 95, 13030-13035. [CrossRef]

41. Huang, W.; Chung, U.I.; Kronenberg, H.M.; de Crombrugghe, B. The Chondrogenic Transcription Factor Sox9 Is a Target of Signaling by the Parathyroid Hormone-Related Peptide in the Growth Plate of Endochondral Bones. Proc. Natl. Acad. Sci. USA 2001, 98, 160-165. [CrossRef]

42. Correa, D.; Hesse, E.; Seriwatanachai, D.; Kiviranta, R.; Saito, H.; Yamana, K.; Neff, L.; Atfi, A.; Coillard, L.; Sitara, D.; et al. Zfp521 Is a Target Gene and Key Effector of Parathyroid Hormone-Related Peptide Signaling in Growth Plate Chondrocytes. Dev. Cell. 2010, 19, 533-546. [CrossRef]

43. Guo, J.; Chung, U.-I.; Kondo, H.; Bringhurst, F.R.; Kronenberg, H.M. The PTH/PTHrP Receptor Can Delay Chondrocyte Hypertrophy in Vivo without Activating Phospholipase C. Dev. Cell. 2002, 3, 183-194. [CrossRef]

44. Lee, K.; Deeds, J.D.; Segre, G.V. Expression of Parathyroid Hormone-Related Peptide and Its Receptor Messenger Ribonucleic Acids during Fetal Development of Rats. Endocrinology 1995, 136, 453-463. [CrossRef]

45. Suda, N.; Gillespie, M.T.; Traianedes, K.; Zhou, H.; Ho, P.W.; Hards, D.K.; Allan, E.H.; Martin, T.J.; Moseley, J.M. Expression of Parathyroid Hormone-Related Protein in Cells of Osteoblast Lineage. J. Cell. Physiol. 1996, 166, 94-104. [CrossRef]

46. Wang, M.; Nasiri, A.R.; Broadus, A.E.; Tommasini, S.M. Periosteal PTHrP Regulates Cortical Bone Remodeling During Fracture Healing. Bone 2015, 81, 104-111. [CrossRef]

47. Blomstrand, S.; Claësson, I.; Säve-Söderbergh, J. A Case of Lethal Congenital Dwarfism with Accelerated Skeletal Maturation. Pediatr. Radiol. 1985, 15, 141-143. [CrossRef] [PubMed]

48. Oostra, R.J.; van der Harten, J.J.; Rijnders, W.P.; Scott, R.J.; Young, M.P.; Trump, D. Blomstrand Osteochondrodysplasia: Three Novel Cases and Histological Evidence for Heterogeneity. Virchows Arch. 2000, 436, 28-35. [CrossRef]

49. Jüppner, H.; Schipani, E. Receptors for Parathyroid Hormone and Parathyroid Hormone-Related Peptide: From Molecular Cloning to Definition of Diseases. Curr. Opin. Nephrol. Hypertens. 1996, 5, 300-306. [CrossRef]

50. Duchatelet, S.; Ostergaard, E.; Cortes, D.; Lemainque, A.; Julier, C. Recessive Mutations in PTHR1 Cause Contrasting Skeletal Dysplasias in Eiken and Blomstrand Syndromes. Hum. Mol. Genet. 2005, 14, 1-5. [CrossRef] [PubMed]

51. Klopocki, E.; Hennig, B.P.; Dathe, K.; Koll, R.; de Ravel, T.; Baten, E.; Blom, E.; Gillerot, Y.; Weigel, J.F.W.; Krüger, G.; et al. Deletion and Point Mutations of PTHLH Cause Brachydactyly Type E. Am. J. Hum. Genet. 2010, 86, 434-439. [CrossRef]

52. Silve, C.; Le-Stunff, C.; Motte, E.; Gunes, Y.; Linglart, A.; Clauser, E. Acrodysostosis Syndromes. Bonekey Rep. $2012,1,225$. [CrossRef]

53. Linglart, A.; Fryssira, H.; Hiort, O.; Holterhus, P.-M.; Perez de Nanclares, G.; Argente, J.; Heinrichs, C.; Kuechler, A.; Mantovani, G.; Leheup, B.; et al. PRKAR1A and PDE4D Mutations Cause Acrodysostosis but Two Distinct Syndromes with or without GPCR-Signaling Hormone Resistance. J. Clin. Endocrinol. Metab. 2012, 97, E2328-E2338. [CrossRef]

54. Patten, J.L.; Johns, D.R.; Valle, D.; Eil, C.; Gruppuso, P.A.; Steele, G.; Smallwood, P.M.; Levine, M.A. Mutation in the Gene Encoding the Stimulatory G Protein of Adenylate Cyclase in Albright's Hereditary Osteodystrophy. N. Engl. J. Med. 1990, 322, 1412-1419. [CrossRef]

55. Weinstein, L.S.; Gejman, P.V.; Friedman, E.; Kadowaki, T.; Collins, R.M.; Gershon, E.S.; Spiegel, A.M. Mutations of the Gs Alpha-Subunit Gene in Albright Hereditary Osteodystrophy Detected by Denaturing Gradient Gel Electrophoresis. Proc. Natl. Acad. Sci. USA 1990, 87, 8287-8290. [CrossRef]

56. Mantovani, G.; de Sanctis, L.; Barbieri, A.M.; Elli, F.M.; Bollati, V.; Vaira, V.; Labarile, P.; Bondioni, S.; Peverelli, E.; Lania, A.G.; et al. Pseudohypoparathyroidism and GNAS Epigenetic Defects: Clinical Evaluation of Albright Hereditary Osteodystrophy and Molecular Analysis in 40 Patients. J. Clin. Endocrinol. Metab. 2010, 95, 651-658. [CrossRef]

57. Alman, B.A.; Greel, D.A.; Wolfe, H.J. Activating Mutations of Gs Protein in Monostotic Fibrous Lesions of Bone. J. Orthop. Res. 1996, 14, 311-315. [CrossRef]

58. Weinstein, L.S.; Shenker, A.; Gejman, P.V.; Merino, M.J.; Friedman, E.; Spiegel, A.M. Activating Mutations of the Stimulatory G Protein in the McCune-Albright Syndrome. N. Engl. J. Med. 1991, 325, 1688-1695. [CrossRef]

59. Landis, C.A.; Masters, S.B.; Spada, A.; Pace, A.M.; Bourne, H.R.; Vallar, L. GTPase Inhibiting Mutations Activate the Alpha Chain of Gs and Stimulate Adenylyl Cyclase in Human Pituitary Tumours. Nature 1989, 340, 692-696. [CrossRef]

60. Williams, S.R.; Aldred, M.A.; Der Kaloustian, V.M.; Halal, F.; Gowans, G.; McLeod, D.R.; Zondag, S.; Toriello, H.V.; Magenis, R.E.; Elsea, S.H. Haploinsufficiency of HDAC4 Causes Brachydactyly Mental Retardation Syndrome, with Brachydactyly Type E, Developmental Delays, and Behavioral Problems. Am. J. Hum. Genet. 2010, 87, 219-228. [CrossRef]

61. Katoh, M. WNT and FGF Gene Clusters (Review). Int. J. Oncol. 2002, 21, 1269-1273. [CrossRef] 
62. Van Amerongen, R.; Nusse, R. Towards an Integrated View of Wnt Signaling in Development. Development 2009, 136, 3205-3214. [CrossRef]

63. Kumar, D.; Lassar, A.B. The Transcriptional Activity of Sox9 in Chondrocytes Is Regulated by RhoA Signaling and Actin Polymerization. Mol. Cell. Biol. 2009, 29, 4262-4273. [CrossRef]

64. Maupin, K.A.; Droscha, C.J.; Williams, B.O. A Comprehensive Overview of Skeletal Phenotypes Associated with Alterations in Wnt/ $\beta$-Catenin Signaling in Humans and Mice. Bone Res. 2013, 1, 27-71. [CrossRef]

65. Li, Y.; Dudley, A.T. Noncanonical Frizzled Signaling Regulates Cell Polarity of Growth Plate Chondrocytes. Development 2009, 136, 1083-1092. [CrossRef]

66. Yang, Y.; Topol, L.; Lee, H.; Wu, J. Wnt5a and Wnt5b Exhibit Distinct Activities in Coordinating Chondrocyte Proliferation and Differentiation. Development 2003, 130, 1003-1015. [CrossRef]

67. Hartmann, C.; Tabin, C.J. Dual Roles of Wnt Signaling during Chondrogenesis in the Chicken Limb. Development 2000, 127, 3141-3159. [PubMed]

68. Day, T.F.; Guo, X.; Garrett-Beal, L.; Yang, Y. Wnt/Beta-Catenin Signaling in Mesenchymal Progenitors Controls Osteoblast and Chondrocyte Differentiation during Vertebrate Skeletogenesis. Dev. Cell. 2005, 8, 739-750. [CrossRef] [PubMed]

69. Hill, T.P.; Später, D.; Taketo, M.M.; Birchmeier, W.; Hartmann, C. Canonical Wnt/Beta-Catenin Signaling Prevents Osteoblasts from Differentiating into Chondrocytes. Dev. Cell. 2005, 8, 727-738. [CrossRef] [PubMed]

70. Hu, H.; Hilton, M.J.; Tu, X.; Yu, K.; Ornitz, D.M.; Long, F. Sequential Roles of Hedgehog and Wnt Signaling in Osteoblast Development. Development 2005, 132, 49-60. [CrossRef]

71. Bennett, C.N.; Ouyang, H.; Ma, Y.L.; Zeng, Q.; Gerin, I.; Sousa, K.M.; Lane, T.F.; Krishnan, V.; Hankenson, K.D.; MacDougald, O.A. Wnt10b Increases Postnatal Bone Formation by Enhancing Osteoblast Differentiation. J. Bone Miner. Res. 2007, 22, 1924-1932. [CrossRef] [PubMed]

72. Lu, Y.; Ren, X.; Wang, Y.; Bardai, G.; Sturm, M.; Dai, Y.; Riess, O.; Zhang, Y.; Li, H.; Li, T.; et al. Novel WNT1 Mutations in Children with Osteogenesis Imperfecta: Clinical and Functional Characterization. Bone 2018, 114, 144-149. [CrossRef] [PubMed]

73. Niemann, S.; Zhao, C.; Pascu, F.; Stahl, U.; Aulepp, U.; Niswander, L.; Weber, J.L.; Müller, U. Homozygous WNT3 Mutation Causes Tetra-Amelia in a Large Consanguineous Family. Am. J. Hum. Genet. 2004, 74, 558-563. [CrossRef] [PubMed]

74. Person, A.D.; Beiraghi, S.; Sieben, C.M.; Hermanson, S.; Neumann, A.N.; Robu, M.E.; Schleiffarth, J.R.; Billington, C.J.; van Bokhoven, H.; Hoogeboom, J.M.; et al. WNT5A Mutations in Patients with Autosomal Dominant Robinow Syndrome. Dev. Dyn. 2010, 239, 327-337. [CrossRef] [PubMed]

75. Thiele, H.; McCann, C.; van't Padje, S.; Schwabe, G.C.; Hennies, H.C.; Camera, G.; Opitz, J.; Laxova, R.; Mundlos, S.; Nürnberg, P. Acropectorovertebral Dysgenesis (F Syndrome) Maps to Chromosome 2q36. J. Med. Genet. 2004, 41, 213-218. [CrossRef] [PubMed]

76. Woods, C.G.; Stricker, S.; Seemann, P.; Stern, R.; Cox, J.; Sherridan, E.; Roberts, E.; Springell, K.; Scott, S.; Karbani, G.; et al. Mutations in WNT7A Cause a Range of Limb Malformations, Including Fuhrmann Syndrome and Al-Awadi/Raas-Rothschild/Schinzel Phocomelia Syndrome. Am. J. Hum. Genet. 2006, 79, 402-408. [CrossRef]

77. Kantaputra, P.N.; Kapoor, S.; Verma, P.; Intachai, W.; Ketudat Cairns, J.R. Split Hand-Foot Malformation and a Novel WNT10B Mutation. Eur. J. Med. Genet. 2018, 61, 372-375. [CrossRef]

78. Huybrechts, Y.; Mortier, G.; Boudin, E.; Van Hul, W. WNT Signaling and Bone: Lessons from Skeletal Dysplasias and Disorders. Front. Endocrinol. 2020, 11, 165. [CrossRef]

79. Saal, H.M.; Prows, C.A.; Guerreiro, I.; Donlin, M.; Knudson, L.; Sund, K.L.; Chang, C.-F.; Brugmann, S.A.; Stottmann, R.W. A Mutation in FRIZZLED2 Impairs Wnt Signaling and Causes Autosomal Dominant Omodysplasia. Hum. Mol. Genet. 2015, 24, 3399-3409. [CrossRef]

80. Schwabe, G.C.; Tinschert, S.; Buschow, C.; Meinecke, P.; Wolff, G.; Gillessen-Kaesbach, G.; Oldridge, M.; Wilkie, A.O.; Kömec, R.; Mundlos, S. Distinct Mutations in the Receptor Tyrosine Kinase Gene ROR2 Cause Brachydactyly Type B. Am. J. Hum. Genet. 2000, 67, 822-831. [CrossRef]

81. Afzal, A.R.; Jeffery, S. One Gene, Two Phenotypes: ROR2 Mutations in Autosomal Recessive Robinow Syndrome and Autosomal Dominant Brachydactyly Type B. Hum. Mutat. 2003, 22, 1-11. [CrossRef]

82. Levasseur, R.; Lacombe, D.; de Vernejoul, M.C. LRP5 Mutations in Osteoporosis-Pseudoglioma Syndrome and High-Bone-Mass Disorders. Jt. Bone Spine 2005, 72, 207-214. [CrossRef] [PubMed]

83. Kwee, M.L.; Balemans, W.; Cleiren, E.; Gille, J.J.P.; Van Der Blij, F.; Sepers, J.M.; Van Hul, W. An Autosomal Dominant High Bone Mass Phenotype in Association with Craniosynostosis in an Extended Family Is Caused by an LRP5 Missense Mutation. J. Bone Miner. Res. 2005, 20, 1254-1260. [CrossRef]

84. Korvala, J.; Jüppner, H.; Mäkitie, O.; Sochett, E.; Schnabel, D.; Mora, S.; Bartels, C.F.; Warman, M.L.; Deraska, D.; Cole, W.G.; et al. Mutations in LRP5 Cause Primary Osteoporosis without Features of OI by Reducing Wnt Signaling Activity. BMC Med. Genet. 2012, 13, 26. [CrossRef] [PubMed]

85. Fijalkowski, I.; Geets, E.; Steenackers, E.; Van Hoof, V.; Ramos, F.J.; Mortier, G.; Fortuna, A.M.; Van Hul, W.; Boudin, E. A Novel Domain-Specific Mutation in a Sclerosteosis Patient Suggests a Role of LRP4 as an Anchor for Sclerostin in Human Bone. J. Bone Miner. Res. 2016, 31, 874-881. [CrossRef] [PubMed]

86. Khan, T.N.; Klar, J.; Ali, Z.; Khan, F.; Baig, S.M.; Dahl, N. Cenani-Lenz Syndrome Restricted to Limb and Kidney Anomalies Associated with a Novel LRP4 Missense Mutation. Eur. J. Med. Genet. 2013, 56, 371-374. [CrossRef] [PubMed] 
87. Kariminejad, A.; Stollfuß, B.; Li, Y.; Bögershausen, N.; Boss, K.; Hennekam, R.C.M.; Wollnik, B. Severe Cenani-Lenz Syndrome Caused by Loss of LRP4 Function. Am. J. Med. Genet. Part A 2013, 161A, 1475-1479. [CrossRef]

88. Little, R.D.; Recker, R.R.; Johnson, M.L. High Bone Density Due to a Mutation in LDL-Receptor-Related Protein 5. N. Engl. J. Med. 2002, 347, 943-944. [CrossRef]

89. Perdu, B.; de Freitas, F.; Frints, S.G.M.; Schouten, M.; Schrander-Stumpel, C.; Barbosa, M.; Pinto-Basto, J.; Reis-Lima, M.; de Vernejoul, M.-C.; Becker, K.; et al. Osteopathia Striata with Cranial Sclerosis Owing to WTX Gene Defect. J. Bone Miner. Res. 2010, 25, 82-90. [CrossRef]

90. Andersson, E.R.; Sandberg, R.; Lendahl, U. Notch Signaling: Simplicity in Design, Versatility in Function. Development 2011, 138, 3593-3612. [CrossRef]

91. Kopan, R.; Goate, A. A Common Enzyme Connects Notch Signaling and Alzheimer's Disease. Genes Dev. 2000, 14, $2799-2806$. [CrossRef] [PubMed]

92. Kopan, R.; Ilagan, M.X.G. The Canonical Notch Signaling Pathway: Unfolding the Activation Mechanism. Cell 2009, 137, $216-233$. [CrossRef]

93. Engin, F.; Lee, B. NOTCHing the Bone: Insights into Multi-Functionality. Bone 2010, 46, 274-280. [CrossRef]

94. Dong, Y.; Jesse, A.M.; Kohn, A.; Gunnell, L.M.; Honjo, T.; Zuscik, M.J.; O’Keefe, R.J.; Hilton, M.J. RBPjkappa-Dependent Notch Signaling Regulates Mesenchymal Progenitor Cell Proliferation and Differentiation during Skeletal Development. Development 2010, 137, 1461-1471. [CrossRef]

95. Mead, T.J.; Yutzey, K.E. Notch Pathway Regulation of Chondrocyte Differentiation and Proliferation during Appendicular and Axial Skeleton Development. Proc. Natl. Acad. Sci. USA 2009, 106, 14420-14425. [CrossRef] [PubMed]

96. Hosaka, Y.; Saito, T.; Sugita, S.; Hikata, T.; Kobayashi, H.; Fukai, A.; Taniguchi, Y.; Hirata, M.; Akiyama, H.; Chung, U.; et al. Notch Signaling in Chondrocytes Modulates Endochondral Ossification and Osteoarthritis Development. Proc. Natl. Acad. Sci. USA 2013, 110, 1875-1880. [CrossRef] [PubMed]

97. Chen, S.; Tao, J.; Bae, Y.; Jiang, M.-M.; Bertin, T.; Chen, Y.; Yang, T.; Lee, B. Notch Gain of Function Inhibits Chondrocyte Differentiation via Rbpj-Dependent Suppression of Sox9. J. Bone Miner. Res. 2013, 28, 649-659. [CrossRef] [PubMed]

98. Feller, J.; Schneider, A.; Schuster-Gossler, K.; Gossler, A. Noncyclic Notch Activity in the Presomitic Mesoderm Demonstrates Uncoupling of Somite Compartmentalization and Boundary Formation. Genes Dev. 2008, 22, 2166-2171. [CrossRef]

99. Ferjentsik, Z.; Hayashi, S.; Dale, J.K.; Bessho, Y.; Herreman, A.; De Strooper, B.; del Monte, G.; de la Pompa, J.L.; Maroto, M. Notch Is a Critical Component of the Mouse Somitogenesis Oscillator and Is Essential for the Formation of the Somites. PLoS Genet. 2009, 5, e1000662. [CrossRef] [PubMed]

100. Bulman, M.P.; Kusumi, K.; Frayling, T.M.; McKeown, C.; Garrett, C.; Lander, E.S.; Krumlauf, R.; Hattersley, A.T.; Ellard, S.; Turnpenny, P.D. Mutations in the Human Delta Homologue, DLL3, Cause Axial Skeletal Defects in Spondylocostal Dysostosis. Nat. Genet. 2000, 24, 438-441. [CrossRef]

101. Kusumi, K.; Sun, E.S.; Kerrebrock, A.W.; Bronson, R.T.; Chi, D.C.; Bulotsky, M.S.; Spencer, J.B.; Birren, B.W.; Frankel, W.N.; Lander, E.S. The Mouse Pudgy Mutation Disrupts Delta Homologue Dll3 and Initiation of Early Somite Boundaries. Nat. Genet. 1998, 19, 274-278. [CrossRef]

102. Bessho, Y.; Sakata, R.; Komatsu, S.; Shiota, K.; Yamada, S.; Kageyama, R. Dynamic Expression and Essential Functions of Hes7 in Somite Segmentation. Genes Dev. 2001, 15, 2642-2647. [CrossRef] [PubMed]

103. Sparrow, D.B.; Chapman, G.; Wouters, M.A.; Whittock, N.V.; Ellard, S.; Fatkin, D.; Turnpenny, P.D.; Kusumi, K.; Sillence, D.; Dunwoodie, S.L. Mutation of the LUNATIC FRINGE Gene in Humans Causes Spondylocostal Dysostosis with a Severe Vertebral Phenotype. Am. J. Hum. Genet. 2006, 78, 28-37. [CrossRef]

104. Sparrow, D.B.; Guillén-Navarro, E.; Fatkin, D.; Dunwoodie, S.L. Mutation of Hairy-and-Enhancer-of-Split-7 in Humans Causes Spondylocostal Dysostosis. Hum. Mol. Genet. 2008, 17, 3761-3766. [CrossRef]

105. Sparrow, D.B.; Sillence, D.; Wouters, M.A.; Turnpenny, P.D.; Dunwoodie, S.L. Two Novel Missense Mutations in HAIRY-ANDENHANCER-OF-SPLIT-7 in a Family with Spondylocostal Dysostosis. Eur. J. Hum. Genet. 2010, 18, 674-679. [CrossRef]

106. Pakvasa, M.; Haravu, P.; Boachie-Mensah, M.; Jones, A.; Coalson, E.; Liao, J.; Zeng, Z.; Wu, D.; Qin, K.; Wu, X.; et al. Notch Signaling: Its Essential Roles in Bone and Craniofacial Development. Genes Dis. 2020, S2352304220300581. [CrossRef] [PubMed]

107. Regan, J.; Long, F. Notch Signaling and Bone Remodeling. Curr. Osteoporos. Rep. 2013, 11, 126-129. [CrossRef]

108. Tu, X.; Chen, J.; Lim, J.; Karner, C.M.; Lee, S.-Y.; Heisig, J.; Wiese, C.; Surendran, K.; Kopan, R.; Gessler, M.; et al. Physiological Notch Signaling Maintains Bone Homeostasis via RBPjk and Hey Upstream of NFATc1. PLoS Genet. 2012, 8, e1002577. [CrossRef]

109. Hilton, M.J.; Tu, X.; Wu, X.; Bai, S.; Zhao, H.; Kobayashi, T.; Kronenberg, H.M.; Teitelbaum, S.L.; Ross, F.P.; Kopan, R.; et al. Notch Signaling Maintains Bone Marrow Mesenchymal Progenitors by Suppressing Osteoblast Differentiation. Nat. Med. 2008, 14, 306-314. [CrossRef]

110. Engin, F.; Yao, Z.; Yang, T.; Zhou, G.; Bertin, T.; Jiang, M.M.; Chen, Y.; Wang, L.; Zheng, H.; Sutton, R.E.; et al. Dimorphic Effects of Notch Signaling in Bone Homeostasis. Nat. Med. 2008, 14, 299-305. [CrossRef] [PubMed]

111. Isidor, B.; Lindenbaum, P.; Pichon, O.; Bézieau, S.; Dina, C.; Jacquemont, S.; Martin-Coignard, D.; Thauvin-Robinet, C.; Le Merrer, M.; Mandel, J.-L.; et al. Truncating Mutations in the Last Exon of NOTCH2 Cause a Rare Skeletal Disorder with Osteoporosis. Nat. Genet. 2011, 43, 306-308. [CrossRef]

112. Canalis, E.; Zanotti, S. Hajdu-Cheney Syndrome, a Disease Associated with NOTCH2 Mutations. Curr. Osteoporos. Rep. 2016, 14, 126-131. [CrossRef] 
113. Hassed, S.; Li, S.; Mulvihill, J.; Aston, C.; Palmer, S. Adams-Oliver Syndrome Review of the Literature: Refining the Diagnostic Phenotype. Am. J. Med. Genet. Part A 2017, 173, 790-800. [CrossRef]

114. Dudoignon, B.; Huber, C.; Michot, C.; Di Rocco, F.; Girard, M.; Lyonnet, S.; Rio, M.; Rabia, S.H.; Daire, V.C.; Baujat, G. Expanding the Phenotype in Adams-Oliver Syndrome Correlating with the Genotype. Am. J. Med. Genet. Part A 2020, 182, 29-37. [CrossRef]

115. Feng, X.-H.; Derynck, R. Specificity and Versatility in Tgf-Beta Signaling through Smads. Annu. Rev. Cell. Dev. Biol. 2005, 21, 659-693. [CrossRef]

116. Wagner, D.O.; Sieber, C.; Bhushan, R.; Börgermann, J.H.; Graf, D.; Knaus, P. BMPs: From Bone to Body Morphogenetic Proteins. Sci. Signal. 2010, 3, mr1. [CrossRef]

117. Yi, J.J.; Barnes, A.P.; Hand, R.; Polleux, F.; Ehlers, M.D. TGF-Beta Signaling Specifies Axons during Brain Development. Cell 2010, 142, 144-157. [CrossRef]

118. Wu, M.; Chen, G.; Li, Y.-P. TGF- $\beta$ and BMP Signaling in Osteoblast, Skeletal Development, and Bone Formation, Homeostasis and Disease. Bone Res. 2016, 4, 16009. [CrossRef]

119. Furumatsu, T.; Ozaki, T.; Asahara, H. Smad3 Activates the Sox9-Dependent Transcription on Chromatin. Int. J. Biochem. Cell. Biol. 2009, 41, 1198-1204. [CrossRef]

120. Mueller, M.B.; Tuan, R.S. Functional Characterization of Hypertrophy in Chondrogenesis of Human Mesenchymal Stem Cells. Arthritis Rheum. 2008, 58, 1377-1388. [CrossRef]

121. Li, X.; Ionescu, A.M.; Schwarz, E.M.; Zhang, X.; Drissi, H.; Puzas, J.E.; Rosier, R.N.; Zuscik, M.J.; O’Keefe, R.J. Smad6 Is Induced by BMP-2 and Modulates Chondrocyte Differentiation. J. Orthop. Res. 2003, 21, 908-913. [CrossRef]

122. Culbert, A.L.; Chakkalakal, S.A.; Theosmy, E.G.; Brennan, T.A.; Kaplan, F.S.; Shore, E.M. Alk2 Regulates Early Chondrogenic Fate in Fibrodysplasia Ossificans Progressiva Heterotopic Endochondral Ossification. Stem Cells 2014, 32, 1289-1300. [CrossRef]

123. Derynck, R.; Akhurst, R.J. Differentiation Plasticity Regulated by TGF-Beta Family Proteins in Development and Disease. Nat. Cell Biol. 2007, 9, 1000-1004. [CrossRef] [PubMed]

124. Loeys, B.L.; Chen, J.; Neptune, E.R.; Judge, D.P.; Podowski, M.; Holm, T.; Meyers, J.; Leitch, C.C.; Katsanis, N.; Sharifi, N.; et al. A Syndrome of Altered Cardiovascular, Craniofacial, Neurocognitive and Skeletal Development Caused by Mutations in TGFBR1 or TGFBR2. Nat. Genet. 2005, 37, 275-281. [CrossRef] [PubMed]

125. Janssens, K.; Vanhoenacker, F.; Bonduelle, M.; Verbruggen, L.; Van Maldergem, L.; Ralston, S.; Guañabens, N.; Migone, N.; Wientroub, S.; Divizia, M.T.; et al. Camurati-Engelmann Disease: Review of the Clinical, Radiological, and Molecular Data of 24 Families and Implications for Diagnosis and Treatment. J. Med. Genet. 2006, 43, 1-11. [CrossRef] [PubMed]

126. Saito, T.; Kinoshita, A.; Yoshiura, K.; Makita, Y.; Wakui, K.; Honke, K.; Niikawa, N.; Taniguchi, N. Domain-Specific Mutations of a Transforming Growth Factor (TGF)-Beta 1 Latency-Associated Peptide Cause Camurati-Engelmann Disease Because of the Formation of a Constitutively Active Form of TGF-Beta 1. J. Biol. Chem. 2001, 276, 11469-11472. [CrossRef]

127. Luu, H.H.; Song, W.-X.; Luo, X.; Manning, D.; Luo, J.; Deng, Z.-L.; Sharff, K.A.; Montag, A.G.; Haydon, R.C.; He, T.-C. Distinct Roles of Bone Morphogenetic Proteins in Osteogenic Differentiation of Mesenchymal Stem Cells. J. Orthop. Res. 2007, $25,665-677$. [CrossRef]

128. Lin, S.; Svoboda, K.K.H.; Feng, J.Q.; Jiang, X. The Biological Function of Type I Receptors of Bone Morphogenetic Protein in Bone. Bone Res. 2016, 4, 16005. [CrossRef]

129. Stange, K.; Désir, J.; Kakar, N.; Mueller, T.D.; Budde, B.S.; Gordon, C.T.; Horn, D.; Seemann, P.; Borck, G. A Hypomorphic BMPR1B Mutation Causes Du Pan Acromesomelic Dysplasia. Orphanet. J. Rare. Dis. 2015, 10, 84. [CrossRef]

130. Tassabehji, M.; Fang, Z.M.; Hilton, E.N.; McGaughran, J.; Zhao, Z.; de Bock, C.E.; Howard, E.; Malass, M.; Donnai, D.; Diwan, A.; et al. Mutations in GDF6 Are Associated with Vertebral Segmentation Defects in Klippel-Feil Syndrome. Hum. Mutat. 2008, 29, 1017-1027. [CrossRef]

131. Le Goff, C.; Michot, C.; Cormier-Daire, V. Myhre Syndrome. Clin. Genet. 2014, 85, 503-513. [CrossRef] [PubMed]

132. Gong, Y.; Krakow, D.; Marcelino, J.; Wilkin, D.; Chitayat, D.; Babul-Hirji, R.; Hudgins, L.; Cremers, C.W.; Cremers, F.P.; Brunner, H.G.; et al. Heterozygous Mutations in the Gene Encoding Noggin Affect Human Joint Morphogenesis. Nat. Genet. 1999, 21, 302-304. [CrossRef] [PubMed]

133. Lehmann, K.; Seemann, P.; Silan, F.; Goecke, T.O.; Irgang, S.; Kjaer, K.W.; Kjaergaard, S.; Mahoney, M.J.; Morlot, S.; Reissner, C.; et al. A New Subtype of Brachydactyly Type B Caused by Point Mutations in the Bone Morphogenetic Protein Antagonist NOGGIN. Am. J. Hum. Genet. 2007, 81, 388-396. [CrossRef] [PubMed]

134. Zong, Z.; Tees, S.; Miyanji, F.; Fauth, C.; Reilly, C.; Lopez, E.; Tredwell, S.; Paul Goldberg, Y.; Delaney, A.; Eydoux, P.; et al. BMPER Variants Associated with a Novel, Attenuated Subtype of Diaphanospondylodysostosis. J. Hum. Genet. 2015, 60, 743-747. [CrossRef]

135. Hellemans, J.; Preobrazhenska, O.; Willaert, A.; Debeer, P.; Verdonk, P.C.M.; Costa, T.; Janssens, K.; Menten, B.; Van Roy, N.; Vermeulen, S.J.T.; et al. Loss-of-Function Mutations in LEMD3 Result in Osteopoikilosis, Buschke-Ollendorff Syndrome and Melorheostosis. Nat. Genet. 2004, 36, 1213-1218. [CrossRef] [PubMed]

136. Doyle, A.J.; Doyle, J.J.; Bessling, S.L.; Maragh, S.; Lindsay, M.E.; Schepers, D.; Gillis, E.; Mortier, G.; Homfray, T.; Sauls, K.; et al. Mutations in the TGF- $\beta$ Repressor SKI Cause Shprintzen-Goldberg Syndrome with Aortic Aneurysm. Nat. Genet. 2012, 44, 1249-1254. [CrossRef]

137. Goetz, R.; Mohammadi, M. Exploring Mechanisms of FGF Signalling through the Lens of Structural Biology. Nat. Rev. Mol. Cell. Biol. 2013, 14, 166-180. [CrossRef] [PubMed] 
138. Ornitz, D.M.; Itoh, N. The Fibroblast Growth Factor Signaling Pathway. Wiley Interdiscip. Rev. Dev. Biol. $2015,4,215-266$. [CrossRef]

139. Jacob, A.L.; Smith, C.; Partanen, J.; Ornitz, D.M. Fibroblast Growth Factor Receptor 1 Signaling in the Osteo-Chondrogenic Cell Lineage Regulates Sequential Steps of Osteoblast Maturation. Dev. Biol. 2006, 296, 315-328. [CrossRef]

140. Ornitz, D.M.; Marie, P.J. FGF Signaling Pathways in Endochondral and Intramembranous Bone Development and Human Genetic Disease. Genes Dev. 2002, 16, 1446-1465. [CrossRef]

141. Iwata, T.; Chen, L.; Li, C.; Ovchinnikov, D.A.; Behringer, R.R.; Francomano, C.A.; Deng, C.X. A Neonatal Lethal Mutation in FGFR3 Uncouples Proliferation and Differentiation of Growth Plate Chondrocytes in Embryos. Hum. Mol. Genet. 2000, 9, 1603-1613. [CrossRef] [PubMed]

142. Hung, I.H.; Yu, K.; Lavine, K.J.; Ornitz, D.M. FGF9 Regulates Early Hypertrophic Chondrocyte Differentiation and Skeletal Vascularization in the Developing Stylopod. Dev. Biol. 2007, 307, 300-313. [CrossRef]

143. Colvin, J.S.; Bohne, B.A.; Harding, G.W.; McEwen, D.G.; Ornitz, D.M. Skeletal Overgrowth and Deafness in Mice Lacking Fibroblast Growth Factor Receptor 3. Nat. Genet. 1996, 12, 390-397. [CrossRef]

144. Iwata, T.; Li, C.L.; Deng, C.X.; Francomano, C.A. Highly Activated Fgfr3 with the K644M Mutation Causes Prolonged Survival in Severe Dwarf Mice. Hum. Mol. Genet. 2001, 10, 1255-1264. [CrossRef]

145. Liu, Z.; Lavine, K.J.; Hung, I.H.; Ornitz, D.M. FGF18 Is Required for Early Chondrocyte Proliferation, Hypertrophy and Vascular Invasion of the Growth Plate. Dev. Biol. 2007, 302, 80-91. [CrossRef] [PubMed]

146. Yu, K.; Xu, J.; Liu, Z.; Sosic, D.; Shao, J.; Olson, E.N.; Towler, D.A.; Ornitz, D.M. Conditional Inactivation of FGF Receptor 2 Reveals an Essential Role for FGF Signaling in the Regulation of Osteoblast Function and Bone Growth. Development 2003, 130, 3063-3074. [CrossRef]

147. Eswarakumar, V.P.; Horowitz, M.C.; Locklin, R.; Morriss-Kay, G.M.; Lonai, P. A Gain-of-Function Mutation of Fgfr2c Demonstrates the Roles of This Receptor Variant in Osteogenesis. Proc. Natl. Acad. Sci. USA 2004, 101, 12555-12560. [CrossRef]

148. Valverde-Franco, G.; Liu, H.; Davidson, D.; Chai, S.; Valderrama-Carvajal, H.; Goltzman, D.; Ornitz, D.M.; Henderson, J.E. Defective Bone Mineralization and Osteopenia in Young Adult FGFR3-/- Mice. Hum. Mol. Genet. 2004, 13, 271-284. [CrossRef]

149. Rousseau, F.; Bonaventure, J.; Legeai-Mallet, L.; Pelet, A.; Rozet, J.M.; Maroteaux, P.; Le Merrer, M.; Munnich, A. Mutations in the Gene Encoding Fibroblast Growth Factor Receptor-3 in Achondroplasia. Nature 1994, 371, 252-254. [CrossRef]

150. Shiang, R.; Thompson, L.M.; Zhu, Y.Z.; Church, D.M.; Fielder, T.J.; Bocian, M.; Winokur, S.T.; Wasmuth, J.J. Mutations in the Transmembrane Domain of FGFR3 Cause the Most Common Genetic Form of Dwarfism, Achondroplasia. Cell 1994, 78, 335-342. [CrossRef]

151. Henderson, J.E.; Naski, M.C.; Aarts, M.M.; Wang, D.; Cheng, L.; Goltzman, D.; Ornitz, D.M. Expression of FGFR3 with the G380R Achondroplasia Mutation Inhibits Proliferation and Maturation of CFK2 Chondrocytic Cells. J. Bone Miner. Res. 2000, 15, 155-165. [CrossRef]

152. Legeai-Mallet, L.; Benoist-Lasselin, C.; Delezoide, A.L.; Munnich, A.; Bonaventure, J. Fibroblast Growth Factor Receptor 3 Mutations Promote Apoptosis but Do Not Alter Chondrocyte Proliferation in Thanatophoric Dysplasia. J. Biol. Chem. 1998, 273, 13007-13014. [CrossRef] [PubMed]

153. Naski, M.C.; Wang, Q.; Xu, J.; Ornitz, D.M. Graded Activation of Fibroblast Growth Factor Receptor 3 by Mutations Causing Achondroplasia and Thanatophoric Dysplasia. Nat. Genet. 1996, 13, 233-237. [CrossRef] [PubMed]

154. Pannier, S.; Couloigner, V.; Messaddeq, N.; Elmaleh-Bergès, M.; Munnich, A.; Romand, R.; Legeai-Mallet, L. Activating Fgfr3 Y367C Mutation Causes Hearing Loss and Inner Ear Defect in a Mouse Model of Chondrodysplasia. Biochim. Biophys. Acta 2009, 1792, 140-147. [CrossRef]

155. Heuertz, S.; Le Merrer, M.; Zabel, B.; Wright, M.; Legeai-Mallet, L.; Cormier-Daire, V.; Gibbs, L.; Bonaventure, J. Novel FGFR3 Mutations Creating Cysteine Residues in the Extracellular Domain of the Receptor Cause Achondroplasia or Severe Forms of Hypochondroplasia. Eur. J. Hum. Genet. 2006, 14, 1240-1247. [CrossRef]

156. Bonaventure, J.; Rousseau, F.; Legeai-Mallet, L.; Le Merrer, M.; Munnich, A.; Maroteaux, P. Common Mutations in the Fibroblast Growth Factor Receptor 3 (FGFR 3) Gene Account for Achondroplasia, Hypochondroplasia, and Thanatophoric Dwarfism. Am. J. Med. Genet. 1996, 63, 148-154. [CrossRef]

157. Cohen, M.M. Achondroplasia, Hypochondroplasia and Thanatophoric Dysplasia: Clinically Related Skeletal Dysplasias That Are Also Related at the Molecular Level. Int. J. Oral. Maxillofac. Surg. 1998, 27, 451-455. [CrossRef]

158. Tavormina, P.L.; Bellus, G.A.; Webster, M.K.; Bamshad, M.J.; Fraley, A.E.; McIntosh, I.; Szabo, J.; Jiang, W.; Jabs, E.W.; Wilcox, W.R.; et al. A Novel Skeletal Dysplasia with Developmental Delay and Acanthosis Nigricans Is Caused by a Lys650Met Mutation in the Fibroblast Growth Factor Receptor 3 Gene. Am. J. Hum. Genet. 1999, 64, 722-731. [CrossRef]

159. Bellus, G.A.; Bamshad, M.J.; Przylepa, K.A.; Dorst, J.; Lee, R.R.; Hurko, O.; Jabs, E.W.; Curry, C.J.; Wilcox, W.R.; Lachman, R.S.; et al. Severe Achondroplasia with Developmental Delay and Acanthosis Nigricans (SADDAN): Phenotypic Analysis of a New Skeletal Dysplasia Caused by a Lys650Met Mutation in Fibroblast Growth Factor Receptor 3. Am. J. Med. Genet. 1999, 85, 53-65. [CrossRef]

160. Toydemir, R.M.; Brassington, A.E.; Bayrak-Toydemir, P.; Krakowiak, P.A.; Jorde, L.B.; Whitby, F.G.; Longo, N.; Viskochil, D.H.; Carey, J.C.; Bamshad, M.J. A Novel Mutation in FGFR3 Causes Camptodactyly, Tall Stature, and Hearing Loss (CATSHL) Syndrome. Am. J. Hum. Genet. 2006, 79, 935-941. [CrossRef] 
161. Makrythanasis, P.; Temtamy, S.; Aglan, M.S.; Otaify, G.A.; Hamamy, H.; Antonarakis, S.E. A Novel Homozygous Mutation in FGFR3 Causes Tall Stature, Severe Lateral Tibial Deviation, Scoliosis, Hearing Impairment, Camptodactyly, and Arachnodactyly. Hum. Mutat. 2014, 35, 959-963. [CrossRef] [PubMed]

162. Rohmann, E.; Brunner, H.G.; Kayserili, H.; Uyguner, O.; Nürnberg, G.; Lew, E.D.; Dobbie, A.; Eswarakumar, V.P.; Uzumcu, A.; Ulubil-Emeroglu, M.; et al. Mutations in Different Components of FGF Signaling in LADD Syndrome. Nat. Genet. 2006, 38, 414-417. [CrossRef] [PubMed]

163. Meyer, M.; Müller, A.-K.; Yang, J.; Moik, D.; Ponzio, G.; Ornitz, D.M.; Grose, R.; Werner, S. FGF Receptors 1 and 2 Are Key Regulators of Keratinocyte Migration in Vitro and in Wounded Skin. J. Cell. Sci. 2012, 125, 5690-5701. [CrossRef]

164. Muenke, M.; Gripp, K.W.; McDonald-McGinn, D.M.; Gaudenz, K.; Whitaker, L.A.; Bartlett, S.P.; Markowitz, R.I.; Robin, N.H.; Nwokoro, N.; Mulvihill, J.J.; et al. A Unique Point Mutation in the Fibroblast Growth Factor Receptor 3 Gene (FGFR3) Defines a New Craniosynostosis Syndrome. Am. J. Hum. Genet. 1997, 60, 555-564. [PubMed]

165. Chun, K.; Siegel-Bartelt, J.; Chitayat, D.; Phillips, J.; Ray, P.N. FGFR2 Mutation Associated with Clinical Manifestations Consistent with Antley-Bixler Syndrome. Am. J. Med. Genet. 1998, 77, 219-224. [CrossRef]

166. Paznekas, W.A.; Cunningham, M.L.; Howard, T.D.; Korf, B.R.; Lipson, M.H.; Grix, A.W.; Feingold, M.; Goldberg, R.; Borochowitz, Z.; Aleck, K.; et al. Genetic Heterogeneity of Saethre-Chotzen Syndrome, Due to TWIST and FGFR Mutations. Am. J. Hum. Genet. 1998, 62, 1370-1380. [CrossRef]

167. Przylepa, K.A.; Paznekas, W.; Zhang, M.; Golabi, M.; Bias, W.; Bamshad, M.J.; Carey, J.C.; Hall, B.D.; Stevenson, R.; Orlow, S.; et al. Fibroblast Growth Factor Receptor 2 Mutations in Beare-Stevenson Cutis Gyrata Syndrome. Nat. Genet. 1996, 13, 492-494. [CrossRef]

168. Muenke, M.; Schell, U.; Hehr, A.; Robin, N.H.; Losken, H.W.; Schinzel, A.; Pulleyn, L.J.; Rutland, P.; Reardon, W.; Malcolm, S. A Common Mutation in the Fibroblast Growth Factor Receptor 1 Gene in Pfeiffer Syndrome. Nat. Genet. 1994, 8, 269-274. [CrossRef]

169. Roscioli, T.; Flanagan, S.; Kumar, P.; Masel, J.; Gattas, M.; Hyland, V.J.; Glass, I.A. Clinical Findings in a Patient with FGFR1 P252R Mutation and Comparison with the Literature. Am. J. Med. Genet. 2000, 93, 22-28. [CrossRef]

170. Simonis, N.; Migeotte, I.; Lambert, N.; Perazzolo, C.; de Silva, D.C.; Dimitrov, B.; Heinrichs, C.; Janssens, S.; Kerr, B.; Mortier, G.; et al. FGFR1 Mutations Cause Hartsfield Syndrome, the Unique Association of Holoprosencephaly and Ectrodactyly. J. Med. Genet. 2013, 50, 585-592. [CrossRef]

171. White, K.E.; Cabral, J.M.; Davis, S.I.; Fishburn, T.; Evans, W.E.; Ichikawa, S.; Fields, J.; Yu, X.; Shaw, N.J.; McLellan, N.J.; et al. Mutations That Cause Osteoglophonic Dysplasia Define Novel Roles for FGFR1 in Bone Elongation. Am. J. Hum. Genet. 2005, 76, 361-367. [CrossRef]

172. Wu, X.-L.; Gu, M.-M.; Huang, L.; Liu, X.-S.; Zhang, H.-X.; Ding, X.-Y.; Xu, J.-Q.; Cui, B.; Wang, L.; Lu, S.-Y.; et al. Multiple Synostoses Syndrome Is Due to a Missense Mutation in Exon 2 of FGF9 Gene. Am. J. Hum. Genet. 2009, 85, 53-63. [CrossRef]

173. Milunsky, J.M.; Zhao, G.; Maher, T.A.; Colby, R.; Everman, D.B. LADD Syndrome Is Caused by FGF10 Mutations. Clin. Genet. 2006, 69, 349-354. [CrossRef]

174. ADHR. Consortium Autosomal Dominant Hypophosphataemic Rickets Is Associated with Mutations in FGF23. Nat. Genet. 2000, 26, 345-348. [CrossRef]

175. Liu, S.; Quarles, L.D. How Fibroblast Growth Factor 23 Works. J. Am. Soc. Nephrol. 2007, 18, 1637-1647. [CrossRef]

176. Ozasa, A.; Komatsu, Y.; Yasoda, A.; Miura, M.; Sakuma, Y.; Nakatsuru, Y.; Arai, H.; Itoh, N.; Nakao, K. Complementary Antagonistic Actions between C-Type Natriuretic Peptide and the MAPK Pathway through FGFR-3 in ATDC5 Cells. Bone 2005, 36, 1056-1064. [CrossRef]

177. Krejci, P. Interaction of Fibroblast Growth Factor and C-Natriuretic Peptide Signaling in Regulation of Chondrocyte Proliferation and Extracellular Matrix Homeostasis. J. Cell Sci. 2005, 118, 5089-5100. [CrossRef]

178. Bartels, C.F.; Bükülmez, H.; Padayatti, P.; Rhee, D.K.; van Ravenswaaij-Arts, C.; Pauli, R.M.; Mundlos, S.; Chitayat, D.; Shih, L.-Y.; Al-Gazali, L.I.; et al. Mutations in the Transmembrane Natriuretic Peptide Receptor NPR-B Impair Skeletal Growth and Cause Acromesomelic Dysplasia, Type Maroteaux. Am. J. Hum. Genet. 2004, 75, 27-34. [CrossRef]

179. Miura, K.; Namba, N.; Fujiwara, M.; Ohata, Y.; Ishida, H.; Kitaoka, T.; Kubota, T.; Hirai, H.; Higuchi, C.; Tsumaki, N.; et al. An Overgrowth Disorder Associated with Excessive Production of CGMP Due to a Gain-of-Function Mutation of the Natriuretic Peptide Receptor 2 Gene. PLoS ONE 2012, 7, e42180. [CrossRef]

180. Barna, M.; Niswander, L. Visualization of Cartilage Formation: Insight into Cellular Properties of Skeletal Progenitors and Chondrodysplasia Syndromes. Dev. Cell. 2007, 12, 931-941. [CrossRef]

181. Smits, P.; Li, P.; Mandel, J.; Zhang, Z.; Deng, J.M.; Behringer, R.R.; de Crombrugghe, B.; Lefebvre, V. The Transcription Factors L-Sox 5 and Sox6 Are Essential for Cartilage Formation. Dev. Cell. 2001, 1, 277-290. [CrossRef]

182. Dy, P.; Wang, W.; Bhattaram, P.; Wang, Q.; Wang, L.; Ballock, R.T.; Lefebvre, V. Sox9 Directs Hypertrophic Maturation and Blocks Osteoblast Differentiation of Growth Plate Chondrocytes. Dev. Cell. 2012, 22, 597-609. [CrossRef]

183. Akiyama, H.; Lyons, J.P.; Mori-Akiyama, Y.; Yang, X.; Zhang, R.; Zhang, Z.; Deng, J.M.; Taketo, M.M.; Nakamura, T.; Behringer, R.R.; et al. Interactions between Sox9 and Beta-Catenin Control Chondrocyte Differentiation. Genes Dev. 2004, 18, 1072-1087. [CrossRef]

184. Topol, L.; Chen, W.; Song, H.; Day, T.F.; Yang, Y. Sox9 Inhibits Wnt Signaling by Promoting Beta-Catenin Phosphorylation in the Nucleus. J. Biol. Chem. 2009, 284, 3323-3333. [CrossRef] [PubMed] 
185. Zhou, G.; Zheng, Q.; Engin, F.; Munivez, E.; Chen, Y.; Sebald, E.; Krakow, D.; Lee, B. Dominance of SOX9 Function over RUNX2 during Skeletogenesis. Proc. Natl. Acad. Sci. USA 2006, 103, 19004-19009. [CrossRef] [PubMed]

186. Hattori, T.; Müller, C.; Gebhard, S.; Bauer, E.; Pausch, F.; Schlund, B.; Bösl, M.R.; Hess, A.; Surmann-Schmitt, C.; von der Mark, H.; et al. SOX9 Is a Major Negative Regulator of Cartilage Vascularization, Bone Marrow Formation and Endochondral Ossification. Development 2010, 137, 901-911. [CrossRef] [PubMed]

187. Leung, V.Y.L.; Gao, B.; Leung, K.K.H.; Melhado, I.G.; Wynn, S.L.; Au, T.Y.K.; Dung, N.W.F.; Lau, J.Y.B.; Mak, A.C.Y.; Chan, D.; et al. SOX9 Governs Differentiation Stage-Specific Gene Expression in Growth Plate Chondrocytes via Direct Concomitant Transactivation and Repression. PLoS Genet. 2011, 7, e1002356. [CrossRef] [PubMed]

188. Foster, J.W.; Dominguez-Steglich, M.A.; Guioli, S.; Kwok, C.; Weller, P.A.; Stevanović, M.; Weissenbach, J.; Mansour, S.; Young, I.D.; Goodfellow, P.N. Campomelic Dysplasia and Autosomal Sex Reversal Caused by Mutations in an SRY-Related Gene. Nature 1994, 372, 525-530. [CrossRef] [PubMed]

189. Wagner, T.; Wirth, J.; Meyer, J.; Zabel, B.; Held, M.; Zimmer, J.; Pasantes, J.; Bricarelli, F.D.; Keutel, J.; Hustert, E.; et al. Autosomal Sex Reversal and Campomelic Dysplasia Are Caused by Mutations in and around the SRY-Related Gene SOX9. Cell 1994, 79, 1111-1120. [CrossRef]

190. Csukasi, F.; Duran, I.; Zhang, W.; Martin, J.H.; Barad, M.; Bamshad, M.; Weis, M.A.; Eyre, D.; Krakow, D.; Cohn, D.H. DominantNegative SOX9 Mutations in Campomelic Dysplasia. Hum. Mutat. 2019, 40, 2344-2352. [CrossRef]

191. Komori, T. Signaling Networks in RUNX2-Dependent Bone Development. J. Cell. Biochem. 2011, 112, 750-755. [CrossRef]

192. Akiyama, H.; Chaboissier, M.-C.; Martin, J.F.; Schedl, A.; de Crombrugghe, B. The Transcription Factor Sox9 Has Essential Roles in Successive Steps of the Chondrocyte Differentiation Pathway and Is Required for Expression of Sox5 and Sox6. Genes Dev. 2002, 16, 2813-2828. [CrossRef]

193. Inada, M.; Yasui, T.; Nomura, S.; Miyake, S.; Deguchi, K.; Himeno, M.; Sato, M.; Yamagiwa, H.; Kimura, T.; Yasui, N.; et al. Maturational Disturbance of Chondrocytes in Cbfa1-Deficient Mice. Dev. Dyn. 1999, 214, 279-290. [CrossRef]

194. Kim, I.S.; Otto, F.; Zabel, B.; Mundlos, S. Regulation of Chondrocyte Differentiation by Cbfa1. Mech. Dev. 1999, 80, 159-170. [CrossRef]

195. Drissi, M.H.; Li, X.; Sheu, T.J.; Zuscik, M.J.; Schwarz, E.M.; Puzas, J.E.; Rosier, R.N.; O’Keefe, R.J. Runx2/Cbfa1 Stimulation by Retinoic Acid Is Potentiated by BMP2 Signaling through Interaction with Smad1 on the Collagen X Promoter in Chondrocytes. J. Cell Biochem. 2003, 90, 1287-1298. [CrossRef] [PubMed]

196. Zheng, Q.; Zhou, G.; Morello, R.; Chen, Y.; Garcia-Rojas, X.; Lee, B. Type X Collagen Gene Regulation by Runx2 Contributes Directly to Its Hypertrophic Chondrocyte-Specific Expression in Vivo. J. Cell. Biol. 2003, 162, 833-842. [CrossRef] [PubMed]

197. Selvamurugan, N.; Pulumati, M.R.; Tyson, D.R.; Partridge, N.C. Parathyroid Hormone Regulation of the Rat Collagenase-3 Promoter by Protein Kinase A-Dependent Transactivation of Core Binding Factor Alpha1. J. Biol. Chem. 2000, 275, 5037-5042. [CrossRef] [PubMed]

198. Javed, A.; Bae, J.-S.; Afzal, F.; Gutierrez, S.; Pratap, J.; Zaidi, S.K.; Lou, Y.; van Wijnen, A.J.; Stein, J.L.; Stein, G.S.; et al. Structural Coupling of Smad and Runx2 for Execution of the BMP2 Osteogenic Signal. J. Biol. Chem. 2008, 283, 8412-8422. [CrossRef] [PubMed]

199. Hinoi, E.; Bialek, P.; Chen, Y.-T.; Rached, M.-T.; Groner, Y.; Behringer, R.R.; Ornitz, D.M.; Karsenty, G. Runx2 Inhibits Chondrocyte Proliferation and Hypertrophy through Its Expression in the Perichondrium. Genes Dev. 2006, 20, 2937-2942. [CrossRef]

200. Stricker, S.; Fundele, R.; Vortkamp, A.; Mundlos, S. Role of Runx Genes in Chondrocyte Differentiation. Dev. Biol. 2002, 245, 95-108. [CrossRef]

201. Qin, X.; Jiang, Q.; Miyazaki, T.; Komori, T. Runx2 Regulates Cranial Suture Closure by Inducing Hedgehog, Fgf, Wnt and Pthlh Signaling Pathway Gene Expressions in Suture Mesenchymal Cells. Hum. Mol. Genet. 2019, 28, 896-911. [CrossRef] [PubMed]

202. Ducy, P.; Starbuck, M.; Priemel, M.; Shen, J.; Pinero, G.; Geoffroy, V.; Amling, M.; Karsenty, G. A Cbfa1-Dependent Genetic Pathway Controls Bone Formation beyond Embryonic Development. Genes Dev. 1999, 13, 1025-1036. [CrossRef] [PubMed]

203. Mundlos, S. Cleidocranial Dysplasia: Clinical and Molecular Genetics. J. Med. Genet. 1999, 36, 177-182.

204. Guo, Y.-W.; Chiu, C.-Y.; Liu, C.-L.; Jap, T.-S.; Lin, L.-Y. Novel Mutation of RUNX2 Gene in a Patient with Cleidocranial Dysplasia. Int. J. Clin. Exp. Pathol. 2015, 8, 1057-1062.

205. Moffatt, P.; Ben Amor, M.; Glorieux, F.H.; Roschger, P.; Klaushofer, K.; Schwartzentruber, J.A.; Paterson, A.D.; Hu, P.; Marshall, C.; FORGE Canada Consortium; et al. Metaphyseal Dysplasia with Maxillary Hypoplasia and Brachydactyly Is Caused by a Duplication in RUNX2. Am. J. Hum. Genet. 2013, 92, 252-258. [CrossRef]

206. Al-Yassin, A.; Calder, A.D.; Harrison, M.; Lester, T.; Lord, H.; Oldridge, M.; Watkins, S.; Keen, R.; Wakeling, E.L. A ThreeGeneration Family with Metaphyseal Dysplasia, Maxillary Hypoplasia and Brachydactyly (MDMHB) Due to Intragenic RUNX2 Duplication. Eur. J. Hum. Genet. 2018, 26, 1288-1293. [CrossRef]

207. Zou, L.; Zou, X.; Li, H.; Mygind, T.; Zeng, Y.; Lü, N.; Bünger, C. Molecular Mechanism of Osteochondroprogenitor Fate Determination during Bone Formation. Adv. Exp. Med. Biol. 2006, 585, 431-441. [CrossRef] [PubMed]

208. Zhou, X.; Zhang, Z.; Feng, J.Q.; Dusevich, V.M.; Sinha, K.; Zhang, H.; Darnay, B.G.; de Crombrugghe, B. Multiple Functions of Osterix Are Required for Bone Growth and Homeostasis in Postnatal Mice. Proc. Natl. Acad. Sci. USA 2010, 107, 12919-12924. [CrossRef] 
209. Nakashima, K.; Zhou, X.; Kunkel, G.; Zhang, Z.; Deng, J.M.; Behringer, R.R.; de Crombrugghe, B. The Novel Zinc FingerContaining Transcription Factor Osterix Is Required for Osteoblast Differentiation and Bone Formation. Cell 2002, 108, 17-29. [CrossRef]

210. Nishimura, R.; Wakabayashi, M.; Hata, K.; Matsubara, T.; Honma, S.; Wakisaka, S.; Kiyonari, H.; Shioi, G.; Yamaguchi, A.; Tsumaki, N.; et al. Osterix Regulates Calcification and Degradation of Chondrogenic Matrices through Matrix Metalloproteinase 13 (MMP13) Expression in Association with Transcription Factor Runx2 during Endochondral Ossification. J. Biol. Chem. 2012, 287, 33179-33190. [CrossRef] [PubMed]

211. Lapunzina, P.; Aglan, M.; Temtamy, S.; Caparrós-Martín, J.A.; Valencia, M.; Letón, R.; Martínez-Glez, V.; Elhossini, R.; Amr, K.; Vilaboa, N.; et al. Identification of a Frameshift Mutation in Osterix in a Patient with Recessive Osteogenesis Imperfecta. Am. J. Hum. Genet. 2010, 87, 110-114. [CrossRef] [PubMed]

212. Offiah, A.C.; Hall, C.M. The Radiologic Diagnosis of Skeletal Dysplasias: Past, Present and Future. Pediatr. Radiol. 2020, 50, 1650-1657. [CrossRef] [PubMed]

213. Calder, A.D.; Irving, M. Pediatric Radiology in the Diagnosis and Management of Skeletal Dysplasias-Welcome to the Era of Genomic Medicine and Modern Drug Pipelines. Pediatr. Radiol. 2020, 50, 1648-1649. [CrossRef] [PubMed]

214. Schirwani, S.; Campbell, J. Genetics for Paediatric Radiologists. Pediatr. Radiol. 2020, 50, 1680-1690. [CrossRef]

215. Marzin, P.; Cormier-Daire, V. New Perspectives on the Treatment of Skeletal Dysplasia. Ther. Adv. Endocrinol. 2020, 11. [CrossRef] [PubMed] 